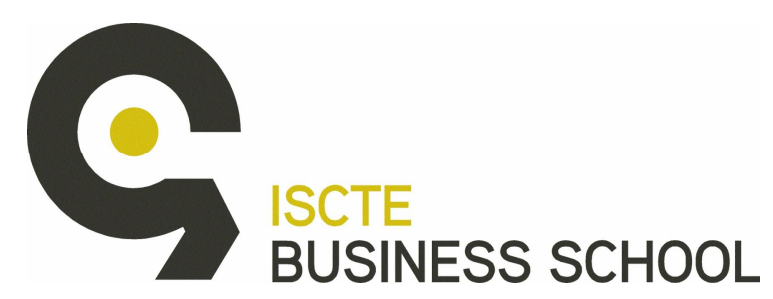

\title{
O ALCOOLISMO NAS ORGANIZAÇÕES ESTUDO DO CASO DA TAP
}

\author{
Sara Alexandra da Silva Amorim Calheiros Lucas \\ Tese submetida como requisito parcial para obtenção do grau de \\ Mestre em Gestão \\ Orientadora: \\ Prof. Doutora Alexandra Fernandes, Prof. Auxiliar, ISCTE Business School, \\ Departamento de Ciências de Gestão
}

Maio 2009 
“As coisas, por si só, não são interessantes, tornam-se interessantes apenas se nos interessamos por elas" (Ceccato, S.) 


\section{RESUMO}

Entende-se por alcoolismo, num sentido amplo, o problema social determinado pelo consumo excessivo de álcool num grupo (Freixa e Soler Insa, 1981 Citado por Gual, 2002). O consumo de bebidas alcoólicas encontra-se profundamente enraizado na cultura ocidental em geral e na mediterrânica em particular, (Ruiloba, 2006) estando de certa forma relacionado com indivíduos de sexo masculino e que trabalham normalmente na construção civil, função pública e forças armadas (Morel et al., 2001).

O abuso de drogas e álcool são o maior dos problemas no local de trabalho. Provocam a mais baixa das produtividades e a taxa mais alta de absentismo (Megia et al., 1995). Quando, no meio laboral, aparece um disfuncionamento ligado ao álcool, instala-se a camuflagem dos erros cometidos ou das falhas graves - esta atitude favorece o desenvolvimento do problema (Ouvrard, 1996).

Relativamente ao álcool a empresa deve centrar-se na obtenção de condições para a sua regressão de modo a aumentar a segurança no trabalho (UGT, 1995).

No âmbito da higiene e segurança no trabalho, iremo-nos debruçar sobre a problemática do alcoolismo nas organizações, por ser um tema que consideramos ter cada vez mais importância, pois são os trabalhadores que sustentam a base da organização.

Nesta tese será ainda retratada a realidade vivida pela TAP - Transportes Aéreos Portugueses em relação a esta problemática.

Palavras-chave: Higiene e Segurança, Trabalho, Alcoolismo, Apoio ao Trabalhador

JEL: J81 - Working Conditions

J83 - Workers' Rights 


\begin{abstract}
It's understood by alcoholism, in a loose sense, the social problem determined by the excessive consume of alcohol on a group (Freixa e Soler Insa, 1981 Citado por Gual, 2002). The consume of alcohols drinks is deep-rooted on the oriental culture in general and on the mediterranean in particular (Ruiloba, 2006) being related in certain way with individuals of the male sex and that usually work at the constructions, civil service and the armed forces (Morel et al., 2001).

The alcohol and drugs abuse are the biggest of the problems at the workplace. It causes the lowest rate of productivity and the highest rate of absenteeism (Megia et al., 1995).

When at the workplace, appears a malfunction connected to alcohol, installs a camouflage of the errors made or the biggest failures - this attitude encourage the development of the problem (Ouvrard, 1996).

Relatively to alcohol the company must focus on the achievement of conditions to it's regression in way to increase the safety at work (UGT, 1995).

We are going to lean over the Alcoholism problem, inside de Safety and Security issue, because we believe it's a theme we consider to have more and more significance, being the employers the foundation of a company.

In this dissertation it will be mentioned the reality lived by the TAP - Portuguese Airline Transports related to this problem.
\end{abstract}

Key-words: Safety and Security, Work, Alcoholism, Worker Support

JEL: J81 - Working Conditions

J83 - Workers' Rights 


\section{AGRADECIMENTOS}

Durante este processo, mais uma fase da minha vida, há muitas pessoas a quem devo uma palavra de agradecimento. A algumas pelo seu conhecimento mas à maioria pelo apoio, essencialmente psicológico, que é um factor fundamental ao longo desta etapa, já que é por vezes difícil ultrapassar algumas barreiras sozinhos.

Em primeiro lugar devo agradecer toda a ajuda prestada pela minha orientadora, a Prof. Doutora Alexandra Fernandes, no que diz respeito à orientação científica, assim como pela sua disponibilidade. Foi de facto uma pessoa que me ajudou a ultrapassar tantos os problemas de execução da tese como a superar a frustração e o desânimo que por vezes é sentido ao longo deste percurso.

Não me posso também esquecer de agradecer ao Prof. Doutor Albino Lopes que além de me ter servido de inspiração para o tema a desenvolver na tese, ajudou-me a encontrar um rumo de desenvolvimento do mesmo.

Devo também agradecer ao Prof. Doutor José Dias Curto, não só pelo apoio ao longo do mestrado como coordenador mas como inspiração ao longo da licenciatura, um professor que faz transparecer o lado humano da educação.

Gostava também de deixar uma palavra de agradecimento à Dr. ${ }^{a}$ Maria Olímpia Mourão e Dr. ${ }^{a}$ Sílvia Baía, sem a vossa ajuda teria sido impossível dar continuidade ao estudo e enquadrá-lo num contexto real.

Claro que não posso deixar de agradecer à minha família, aos meus pais, às minhas irmãs e à minha avó por terem sempre acreditado em mim.

Aos meus amigos, há os que devo agradecer a paciência e a compreensão, a palavra certa no momento exacto, o encorajamento, o esforço, ou a pura vontade de me ouvir. Essencialmente a eles devo o carinho e amizade necessários para ultrapassar os momentos mais difíceis, assim como a alegria da partilha das vitórias. 
A ti minha avó, por teres tornado mais fácil o meu percurso até aqui. 


\section{ÍNDICE}

ÍNDICE i

ÍNDICE DE QUADROS ............................................................................ii

ÍNDICE DE FIGURAS ..............................................................................

ÍNDICE DE ANEXOS .............................................................................

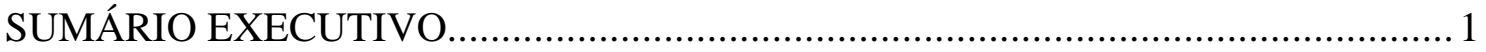

INTRODUÇÃ

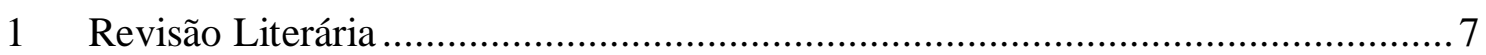

1.1 Higiene e Segurança no trabalho........................................................ 7

1.1.1 Higiene no trabalho.................................................................. 7

1.1.2 Segurança no trabalho .......................................................... 8

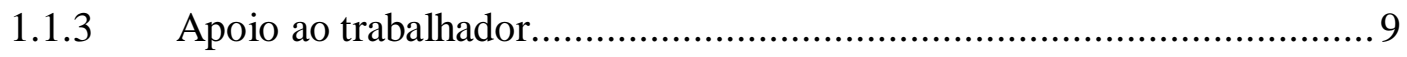

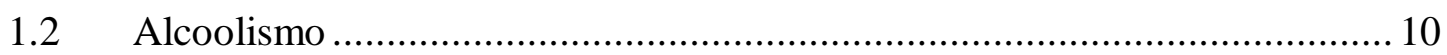

1.2.1 Consequências para a Saúde...................................................... 13

1.2.2 Causas do Alcoolismo..................................................................... 15

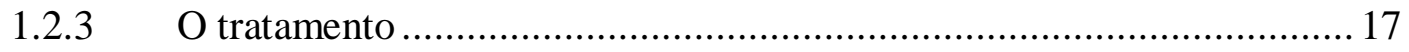

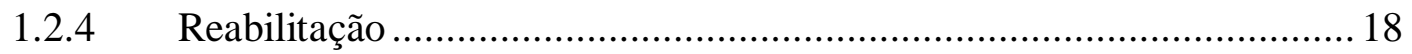

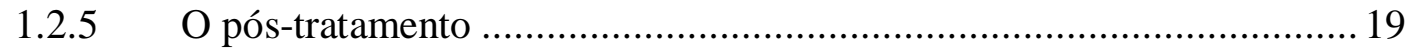

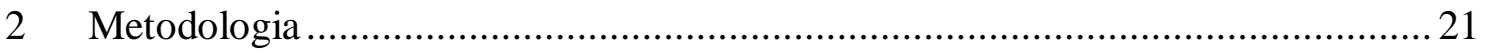

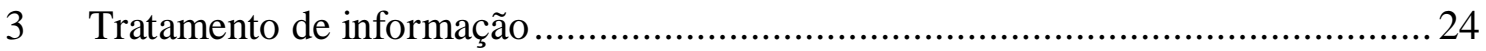

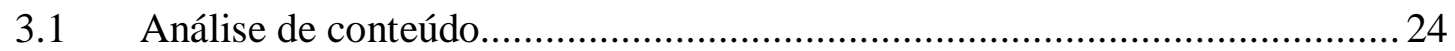

3.1.1 Procedimento para a recolha de dados ............................................ 27

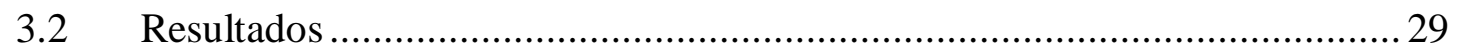

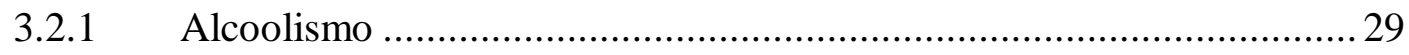


3.2.2 Consequências para a saúde …...................................................... 31

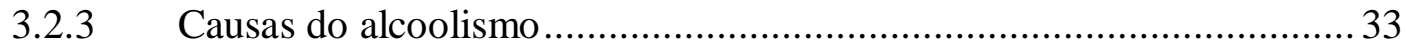

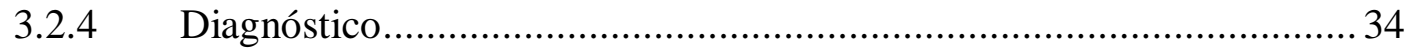

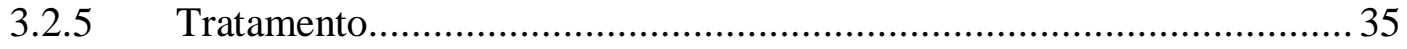

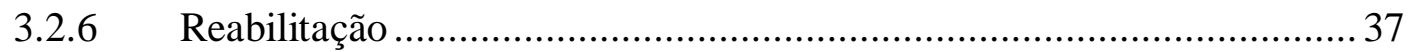

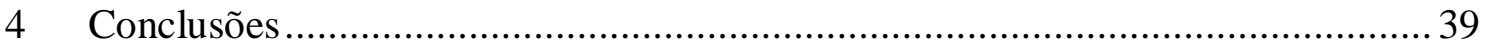

4.1 Limitações e sugestões para futuras investigações.................................... 41

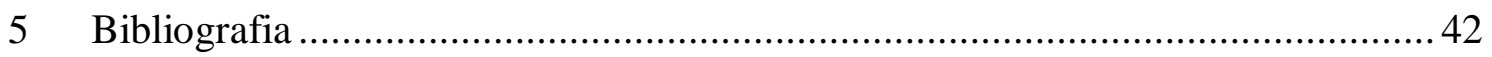

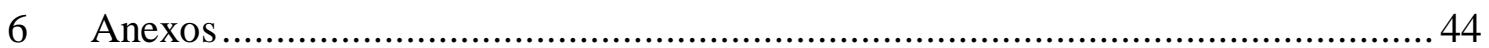




\section{ÍNDICE DE QUADROS}

Tabela 1 - Caracterização dos consumidores e não consumidores de álcool (Gameiro, 1981) .15 


\section{ÍNDICE DE FIGURAS}

Figura 1 - Esquema de análise de conteúdo qualitativa adaptado de (Krippendorff, 2004) .27 


\section{ÍNDICE DE ANEXOS}

Anexo 1 - Guião de entrevista .45

Anexo 2 - Código de Ética da TAP. .48

Anexo 3 - Regulamento Interno de Prevenção e Controlo do Consumo de Álcool, Drogas e Tabaco 60 


\section{SUMÁRIO EXECUTIVO}

Esta dissertação tem como objectivo estudar a problemática do Alcoolismo no contexto organizacional, deste modo, após aprofundarmos os conhecimentos teóricos sobre este tema, tornou-se essencial perceber como é que se processam certos comportamentos dentro de uma empresa do nosso País.

Esta tese centra-se no estudo do Alcoolismo nas Organizações, em termos gerais está dividida em duas partes, na primeira faz-se uma introdução teórica em relação à temática da Higiene e Segurança no trabalho ao Apoio ao trabalhador e ao Alcoolismo. $\mathrm{Na}$ segunda parte é aprofundado o estudo da problemática do Alcoolismo tendo em consideração o estudo de um caso real. Para tal foi essencial a colaboração com a TAP Transportes Aéreos Portugueses, através da qual foi possível passar da teoria à prática.

Segundo Barañano uma investigação é "uma sequência lógica que liga os dados empíricos às questões previamente formuladas e às conclusões alcançadas" (2004:103), como tal começámos por analisar autores que trabalharam sobre estes temas de modo a poder criar uma base sólida que permitiu guiar o nosso estudo. Esta abordagem teórica inicial tem por objectivo fornecer informações suficientes dos aspectos mais relevantes a estudar assim como orientar o desenvolvimento da investigação como um todo, já que determinam os dados a serem recolhidos (Barañano, 2004).

Em termos metodológicos, a opção recaiu pelo estudo de caso. Esta escolha foi também ela apoiada com base em teóricos, e seleccionada pois era a que melhor se adequava ao nosso objectivo de estudo. 
Após a decisão acerca da metodologia a seguir, tivemos de optar por uma forma de analisar informação, e o meio usado foi a entrevista semi-directiva. Esta permite ao entrevistado uma forma mais livre de resposta que um questionário fechado e menos independente que uma técnica não directiva. Desta forma, as respostas não são limitadas mas se o entrevistado começar a divagar sobre outros assuntos que não têm tanto relevo no estudo em causa, o entrevistador tem o poder de dirigir a entrevista para o assunto central. Desta forma, foi elaborado um guião de entrevista já que se "deve clarificar com precisão a natureza das questões em estudo" (Barañano, 2004:103). O guião de entrevista foi aplicado a duas assistentes sociais da TAP que permitiram com a sua colaboração que este estudo avançasse.

Após a recolha da informação torna-se necessário tratá-la e há várias formas de tratamento de informação. No nosso caso decidimos optar pela análise de conteúdo, já que é a melhor opção para o tratamento de informação quando são aplicadas entrevistas e para assim poder retirar da informação recolhida os dados que interessavam ao nosso estudo.

Esta análise permitiu agrupar a informação de modo a que os resultados se tornassem perceptíveis tanto para quem estava a tratar a informação quanto para o leitor.

No final deste processo foi-nos possível retirar algumas conclusões da nossa investigação. Entre as quais foi possível verificar que ao contrário do que se julgava, o assunto alcoolismo dentro de uma organização deixou de ser tabu, isto não impede que as empresas estejam focadas nesta problemática e ajam de forma a evitar a propagação actuando na formação e sensibilização dos trabalhadores.

As consequências deste tipo de comportamento estão patentes ao nível da saúde do indivíduo, mas não deixam de existir ao nível da empresa e nos grupos de trabalho, aparecendo nestes casos sob outras formas.

Maioritariamente os casos de alcoolismo encontram-se enquadrados nas faixas etárias mais novas.

Os casos podem ser identificados de várias formas, incluindo as chefias ou até colegas de trabalho.

O tratamento poderá ocorrer interna ou externamente dependendo da necessidade de internamento do indivíduo. 
Quanto à fase de reabilitação pode acarretar mudanças em relação ao posto de trabalho, por poder significar uma tarefa que necessite de menos precisão ou atenção por parte do trabalhador. 


\section{INTRODUÇÃO}

"Preciso de me lembrar e que me lembrem todas as semanas que sou sempre um alcoólico e que se beber ponho novamente tudo a perder" (Alcoólico Anónimo Citado por Gameiro, 1983:41).

O Alcoolismo é um tema sobre o qual se deve ter uma abordagem delicada, especialmente quando o contexto em estudo é o empresarial. No entanto, é uma realidade proeminente há bastante tempo, e infelizmente uma problemática que está presente no meio laboral, pois não escolhe estratos sociais, cargos, funções, sexo e infelizmente nem idades. Tendo em consideração estes aspectos, torna-se interessante tentar perceber qual a magnitude desta problemática dentro das organizações.

Este tema surge primeiro numa abordagem teórica que incide sobre a Higiene e Segurança no trabalho. As empresas têm como dever assegurar estes direitos aos seus trabalhadores, encontrando-se assente em normas e procedimentos. Isto também pressupõe que criadas as condições por parte da entidade empregadora, os seus funcionários respeitem o que se encontra estabelecido, de modo a que seja possível reduzir ao mínimo os problemas que possam surgir. No entanto, este cenário seria perfeito, se ambas as partes colaborassem em conjunto. Por oposição ao lado idealista a realidade nem sempre permite que as situações ocorram desta forma. Deste modo, torna-se necessário promover a sensibilização e a formação de parte a parte.

O Alcoolismo, surge neste contexto por pôr em risco a integridade física e mental dos trabalhadores, tanto do indivíduo com problemas desta ordem quanto dos que o rodeiam, sendo que esta é também uma das responsabilidades da empresa devendo por isso tentar preservar estes aspectos primordiais. 
É de salientar que sendo os trabalhadores considerados os pilares numa organização, será da maior importância tomar em consideração o quanto esta problemática pode afectar a dinâmica da empresa. Esta perturbação pode acontecer sob várias formas, desde o absentismo, passando por um ambiente de trabalho desagradável, originar conflitos entre os funcionários, podendo até manifestar-se em erros de cálculo e decisão. Estes comportamentos traduzem-se em consequências negativas para a empresa, tornando-se desta forma relevante e interessante estudar esta temática.

Embora seja difícil obter dados sobre o número de alcoólicos que fazem parte da população e que sejam fiéis à realidade, está patente que o problema se encontra enraizado na sociedade. Este estudo não tenta retratar a realidade portuguesa e caracterizá-la com base em estatísticas de consumo de álcool. Tem como objectivo, por um lado, perceber de um modo abrangente quais os deveres das empresas perante os trabalhadores no que diz respeito à Higiene e Segurança no trabalho e de uma forma mais específica como estas se devem comportar em relação ao Alcoolismo.

Depois de efectuada uma teorização sobre o tema, ajuda perceber em termos práticos qual a dimensão do problema, desta forma, tendo em consideração que a problemática do Alcoolismo no âmbito laboral tem mais incidência em contextos específicos, surgiu necessidade de procurar informação numa empresa que nos permitisse tirar conclusões sobre um caso particular. A empresa com quem trabalhámos foi a TAP - Transportes Aéreos Portugueses. Esta empresa já leva de existência seis décadas, tendo sido criada em 1945. Além de ser líder de mercado tem 58 destinos de voo a seu cargo. Uma empresa com tanta história e responsabilidade, conta com a ajuda de bastantes colaboradores desde as áreas do voo propriamente dito até aos mais variados cargos que estão na base da contribuição da prestação da empresa. Além de interessante foi muito útil percepcionar a maneira como a TAP lida com este problema.

De seguida será apresentada uma perspectiva teórica sobre o tema da Higiene e Segurança no trabalho, assim como sobre o Alcoolismo, desde as consequências que acarreta para a saúde, passando pelas possíveis causas da dependência, como se processa o tratamento, e quais as realidades que poderão ser encontradas tanto na fase de reabilitação como após o tratamento. Ainda neste ponto será abordada a questão do apoio ao trabalhador.

No segundo ponto desta dissertação será explicado como se procedeu à escolha da metodologia a usar aquando da recolha de informação. 
O tratamento da informação recolhida aparece retratado no terceiro ponto, onde serão estudados os resultados obtidos através da TAP.

Por último, no ponto 4, serão apresentadas as conclusões que surgiram após o estudo deste tema. 


\section{Revisão Literária}

Neste secção serão abordadas as perspectivas de alguns autores relativamente aos temas da Higiene e Segurança no trabalho numa primeira fase e em seguida será abordada a problemática do Alcoolismo, referindo algumas das consequências para a saúde, causas e possíveis abordagens terapêuticas assim como a reabilitação e o pós-tratamento.

\subsection{Higiene e Segurança no trabalho}

\subsubsection{Higiene no trabalho}

A definição de higiene no trabalho proposta por Chiavenato - " refere-se a um conjunto de normas e procedimentos que visa a protecção da integridade física e mental do trabalhador, preservando-o dos riscos de saúde inerentes às tarefas do cargo e ao ambiente físico onde são executadas" (1993: 353).

Esta encontra-se "relacionada com o diagnóstico e com a prevenção de doenças ocupacionais" a partir do estado do " homem e do seu ambiente de trabalho" (Chiavenato, 1993:354).

Plano de Higiene do trabalho, proposto por Chiavenato (1993):

1. Um plano organizado - prestação de serviços de médicos, enfermeiros e auxiliares. A duração temporal depende do tamanho da empresa;

2. Serviços médicos adequados;

3. Prevenção de riscos à saúde:
a. Químicos
b. Físicos
c. Biológicos 
4. Serviços adicionais - como parte do investimento empresarial sobre a saúde do empregado e da comunidade.

Objectivos da Higiene no trabalho (Chiavenato, 1993)

- Eliminação das causas das doenças profissionais;

- Redução dos efeitos prejudiciais provocados pelo trabalho em pessoas portadoras de defeitos físicos;

- Prevenção do agravamento de doenças e lesões;

- Manutenção da saúde dos trabalhadores;

- Aumento da produtividade através do controlo do ambiente de trabalho.

Para Baptista (Citado por Chiavenato, 1993: 355) esses objectivos poderão ser obtidos:

1. Pela educação dos operários, chefes, capatazes, gerentes, etc, indicando perigos existentes e ensinando como evitá-los;

2. Mantendo constante estado de alerta contra os riscos existentes na fábrica;

3. Pelos estudos e observações dos novos processos ou materiais utilizados.

\subsubsection{Segurança no trabalho}

O problema de segurança envolve necessariamente a adaptação do homem ao trabalho (selecção de pessoal), adaptação do trabalho ao homem (racionalização do trabalho), além de factores sócio-psicológicos, razão pela qual certas organizações vinculam a segurança ao órgão de recursos humanos. Esta visa minimizar os acidentes de trabalho, identificando as causas dos mesmos e os custos directos e indirectos que lhes estão associados (Chiavenato, 1993). 
Programas postos em prática que têm por objectivo ajudar empregados conflituosos e na reabilitação do alcoolismo não foram muito bem sucedidos porque os trabalhadores não gostam de ser apontados como conflituosos (Cherrington, 1995).

\subsubsection{Apoio ao trabalhador}

O apoio ao trabalhador varia conforme a dimensão da empresa, (Cherrington, 1995):

- Empresas mais pequenas usam os seus recursos para assistir os seus empregados, pois não conseguem suportar os custos de ter pessoas especializadas.

- As grandes empresas podem, geralmente, suportar os custos de ter psicólogos e meios próprios para actuarem dentro da empresa.

O mais importante no tratamento é o desejo do trabalhador ser ajudado (Cherrington, 1995).

Este problema de aceitação está normalmente associado à dependência de álcool ou drogas. Os alcoólicos recusam a análise dos mecanismos que estão na origem do consumo excessivo (UGT, 1995). Se o trabalhador nega o seu consumo excessivo de álcool referindo que apenas bebe socialmente, a empresa tem de submeter o empregado a uma avaliação de desempenho e análises comprovando que o mesmo se encontra no estado de alcoolismo sendo lhe dadas duas hipóteses, ou a reabilitação, através de EAPs $^{1}$ ou o despedimento. As consequências individuais e comunitárias do consumo excessivo do álcool foram menosprezadas subconscientemente ou intencionalmente durante muito tempo; porém a partir de 1950, surge uma certa preocupação no seu estudo (Castelão et al., 1987).

As primeiras iniciativas por parte das empresas produziram geralmente regulamentos interditando o consumo de álcool no interior das empresas e promovendo a ajuda a trabalhadores com consumos problemáticos, começou por se optar por medidas de controlo e apoio (Morel et al., 2001).

\footnotetext{
${ }^{1}$ EAPs - employee assistance programs
} 
Os EAPs são programas para ajudar empregados cuja performance no trabalho se encontra afectada devido a problemas físicos mentais ou emocionais. Os primeiros surgiram nos anos 40 em empresas como Du Pont and Eastman Kodak e eram dirigidos ao tratamento do alcoolismo (Megia et al., 1995).

\subsection{Alcoolismo}

Num sentido amplo, entende-se por alcoolismo, o problema social determinado pelo consumo excessivo de álcool num grupo (Freixa e Soler Insa, 1981 (Citado por Gual, 2006)

"Além de existirem consequências negativas em termos de saúde pública, os padrões nocivos e perigosos de consumo de álcool, geram custos ao nível dos cuidados de saúde, provocando efeitos negativos no desenvolvimento económico e na sociedade em geral"' (2009:4). ${ }^{2}$

Programa ${ }^{3}$ de detecção e acção sobre os trabalhadores alcoólicos (Gameiro, 1983):

Logo que é detectado alcoolismo num empregado, este é abordado pelo departamento de pessoal e enviado para o departamento de medicina do trabalho. Após os exames respectivos é posto perante a alternativa: ou demitir-se ou procurar ajuda no serviço adequado que é indicado. É-lhe então dada informação onde pode procurar ajuda sem encargos pessoais.

É a empresa, através da seguradora, que suporta todas as despesas de consultas e tratamento em centro adequado até quatro semanas.

Em certos casos, mais graves, este período pode ser alongado.

No caso de não se tornar necessário a desintoxicação nem o tratamento em centro especializado, o empregado pode ser aconselhado a frequentar, tantos dias por semana as reuniões de AA na área, para através deste programa, reencontrar o caminho da sobriedade.

\footnotetext{
${ }^{2}$ Autor desconhecido in Revista Dependências http://www.dependencias.pt/images/stories/pdfs/dependencias_fevereiro2009.pdf

3 Este programa é seguido por duas empresas, a DU Pont possui um serviço privativo que opera em Willmington (Delawarel) e o pratica desde 1942, o segunda é uma empresa de Baltimore que vende os seus serviços a várias empresas e pratica este programa desde 1981.
} 
Se isto não solucionar o caso, o tratamento em centro é proposto, seguido de tratamento de pós-cura através de reuniões dos $\mathrm{AA}^{4}$. O programa de Alcoólicos Anónimos é o melhor em existência para ajudar os alcoólatras a permanecerem sóbrios, mas não é um veículo particularmente eficaz quando o objectivo principal é tornar o alcoólatra sóbrio (Milan e Ketchan 1986).

Se o empregado aceitar a proposta e deixar de beber, nada lhe acontece em relação ao emprego, mas se continuar na recaída, é suspenso sem vencimento durante 90 dias. $\mathrm{O}$ mesmo acontece àqueles que se tratam em centros e recaem logo a seguir (Gameiro, 1983).

Passados 90 dias de suspensão, se o indivíduo se tornar sóbrio é de novo admitido, em pleno, no emprego (Gameiro, 1983).

Os supervisores têm instruções para encorajar e apoiar os trabalhadores em recuperação contudo têm de continuar a ser rígidos nas ordens e avaliação (Cherrington. 1995).

Estudos feitos na empresa de Willmington, dos 1231 trabalhadores que passaram pelo programa, cerca de $80 \%$ conservaram os seus postos e a percentagem tende a aumentar.

Para as empresas adoptar a prevenção como medida a tomar torna-se economicamente mais sustentável, mas não a mais aceitável do ponto de vista ético (Morel et al, 2001). As empresas que aderiram aos programas de prevenção notaram um aumento da poupança (Gameiro, 1983). Não há dúvida que o álcool está presente em muitas empresas mas o assunto continua a ser tabu. Quando, no meio laboral, aparece um disfuncionamento ligado ao álcool, instala-se a camuflagem dos erros cometidos ou das falhas graves - esta atitude favorece o desenvolvimento do problema (Ouvrard, 1996).

O abuso de drogas e álcool são o maior dos problemas no local de trabalho. Provocam a mais baixa das produtividades e a taxa mais alta de absentismo (Megia et al., 1995) "em especial às segundas-feiras" (Gameiro, 1981:27). O alcoolismo pode vir a tornar-se conhecido apenas 10 ou 15 anos após a sua instalação. Através da pressão dos modelos sociais, o alcoolismo é, em grande parte, epidémica relativamente a certos ambientes (Gameiro, 1981).

\footnotetext{
${ }^{4}$ Alcoólicos Anónimos
} 
Para Megia e outros., o uso de testes de vestígios de drogas/álcool é uma ferramenta utilizada para tornar o local de trabalho mais seguro, eficiente e rentável. Essas análises continuam a ser um assunto controverso, principalmente quando implica a privacidade do empregado. Com o passar dos tempos, estes tendem a aceitar mais os testes, principalmente à medida que vão percebendo as consequências do uso de drogas no trabalho (1995).

"O alcoolismo no meio profissional era geralmente disfarçado, em virtude das ameaças que a descoberta desta situação comporta. Os alcoólicos não eram assinalados senão quando o seu comportamento tomava proporções catastróficas, e eram então rejeitados pela colectividade de trabalho" (Sociedade Anti-Alcoólica Portuguesa, 1976:36).

Numa perspectiva mais recente o patronato não contrata, nem despede empregados com testes positivos. Aposta actualmente em programas de assistência ou outros serviços onde eles conseguem obter ajuda para resolver os seus problemas (Megia et al., 1995).

Relativamente ao álcool a empresa deve centrar-se na obtenção de condições para a sua regressão de modo a aumentar a segurança no trabalho (UGT, 1995).

Trabalhos árduos e a céu aberto, assim como condições pessoais, monotonia, trabalho por turnos, horários desencontrados, trajectos longos e fatigantes (UGT, 1995), são aspectos que podem levar ao trabalhador a consumir álcool. O que leva a empresa actuar sobre as condições em que os seus trabalhadores se encontram e modificá-las, no entanto, muitas não conduzem paralelamente os interesses da empresa e da saúde dos seus funcionários. (Morel et al., 2001).

Pode-se de certa forma delinear um padrão de indivíduos consumidores de álcool de sexo maioritariamente masculino e onde as funções desempenhadas normalmente são a construção civil, função pública e forças armadas (Morel et al., 2001).

O alcoolismo é uma doença causada pelo uso imoderado e repetido de bebidas alcoólicas mantendo o organismo de forma continuada, sob a quantidade de álcool superior às que o fígado pode eliminar. Pode estabelecer-se que a quantidade de álcool ingerido diariamente não deve nunca exceder uma grama de álcool por cada $\mathrm{kg}$ do indivíduo (UGT, 1995). 


\subsubsection{Consequências para a Saúde}

O alcoolismo constitui uma agressão para o organismo e provoca a sua destruição a diversos níveis.

Gameiro (1981) aponta algumas consequências para a saúde:

1. Físicas

Gastrites agudas ou crónicas, possíveis úlceras, cirroses do fígado, perturbações visuais, polinevrite, delirium tremens.

2. Psíquicas

Perturbações da personalidade e de comportamento, irritabilidade, ciúme, apagamento da inteligência e vontade, desinteresse pela família e emprego;

Confusão mental, delírio, demência alcoólica.

3. Sociais

- Perturbação e desagregação da dinâmica da família;

Pode conduzir ao isolamento afectivo, solidão e muitas vezes ao desespero e suicídio

- Integração do indivíduo no seu trabalho.

Relativamente ao último ponto, no que se refere à integração do indivíduo no seu trabalho, pode dar-se o caso de numa primeira fase existir uma integração deficiente na ocupação, que pode levar a uma despromoção e, em muitos casos, a perda repetida e irremediável dos empregos.

"Beber até à embriaguez (intoxicação aguda) produz um efeito de deterioração da capacidade de raciocínio, da tomada de decisões e da capacidade de auto controlo do comportamento. A deterioração da coordenação motora pode causar acidentes e lesões, nomeadamente acidentes rodoviários e laborais" (2009). ${ }^{5}$

\footnotetext{
${ }^{5}$ Autor desconhecido in Revista Dependências http://www.dependencias.pt/images/stories/pdfs/dependencias_fevereiro2009.pdf
} 
De um modo geral pode dizer-se que as relações familiares de um indivíduo, dependente do álcool são desequilibradas, dirigidas pela agressividade, a insegurança e a vergonha. Os profissionais de saúde que trabalham com pessoas alcoólicas são muitas vezes confrontados com os familiares que não bebem e que necessitam de ajuda (Velleman, 2001). Também no trabalho o álcool produz efeitos graves nas relações profissionais degradadas, perda de rendimento, níveis muito elevados de absentismo e acidentes (UGT, 1995).

Segundo a O.M.S. (Citado pela UGT, 1995), os alcoólicos são bebedores excessivos cuja dependência face ao álcool lhes provoca perturbações que afectam a saúde física e mental, as relações com os outros, bem como o comportamento social e económico, devendo portanto ser tratado.

"O consumo de risco corresponde a um tipo de padrão de consumo que provoca o dano se o mesmo persistir; e que aumenta o risco de sofrer doenças, acidentes, lesões, transtornos mentais ou de comportamento" (2009:5). ${ }^{6}$

Gameiro (1981), representou a sociedade segundo os comportamentos que se têm em relação ao álcool. Na tabela seguinte podemos verificar que é expectável das crianças até aos 14 anos, mulheres grávidas e amamentar, assim como doentes nervosos não consumir bebidas com álcool, apesar de não ser sempre este o retrato mais fidedigno da sociedade. Podemos também percepcionar como classificar os tipos de consumidores de álcool.

\footnotetext{
${ }^{6}$ Autor desconhecido in Revista Dependências http://www.dependencias.pt/images/stories/pdfs/dependencias_fevereiro2009.pdf
} 


\begin{tabular}{l|l}
\hline \hline Não bebem & $\begin{array}{l}\text { Crianças até aos 14 anos, mulheres } \\
\text { grávidas, as que amamentam e } \\
\text { doentes nervosos }\end{array}$ \\
\hline $\begin{array}{l}\text { Bebedores } \\
\text { moderados }\end{array}$ & $\begin{array}{l}\text { Bebem segundo critérios de máxima } \\
\text { segurança para a saúde }\end{array}$ \\
\hline Bebedor excessivo & $\begin{array}{l}\text { Por norma bebe mais de 1 Litro de } \\
\text { Vinho (por dia) (10-12 graus) }\end{array}$ \\
\hline Bebedor dependente & $\begin{array}{l}\text { Preso ao produto álcool por um hábito } \\
\text { de dependência tal que não é capaz de } \\
\text { se libertar. }\end{array}$ \\
\hline Alcoólico crónico & $\begin{array}{l}\text { Além de dependente da bebida, } \\
\text { encontra-se já gravemente afectado na } \\
\text { saúde }\end{array}$ \\
\hline \hline
\end{tabular}

Tabela 1 - Caracterização dos consumidores e não consumidores de álcool (Gameiro, 1981)

\subsubsection{Causas do Alcoolismo}

A UGT (1995) aponta algumas causas que podem estar na origem do consumo do álcool:

\section{Factores de ordem individual}

- Temperamento, personalidade, tendências neuróticas, etc.

- Ordem social (educação, família, situação pessoal e profissional, hábitos)

- Ordem económica - produção e comercialização do álcool apoiadas pelo marketing

O consumo de certas substâncias vem reforçar a pertença ao grupo (Morel et al, 2001).

Há também que ter em conta que embora possa haver uma causa para a procura do álcool, há quem nele tente encontrar efeitos adequado à sua atitude. Sendo estes "efeitos psicotrópicos" (Gameiro, 1981:23) da procura do álcool. 
Quando o indivíduo procura desinibir-se, sentir-se bem, procura efeitos estimulantes do álcool, quando por outro lado tenta encontrar no álcool o lado mais depressivo ou ausente, procura os efeitos inibidores (Gameiro, 1981). De certo modo, podemos agrupar estes efeitos em dois pólos opostos, o pólo positivo, onde constam os efeitos estimulantes e o pólo negativo, no qual fazem parte os efeitos inibidores.

No pólo positivo pode verificar-se o efeito euforizante, vasodilatador e excitante.

No pólo negativo há também o efeito depressivo e anestésico.

Todos os que procuram incessantemente estes efeitos no álcool "correm o risco de se encontrar na fase inicial do alcoolismo" (Gameiro, 1981:23).

Segundo a UGT é fundamental, na empresa suscitar a sensibilização geral mediante campanhas de informação, divulgação dos efeitos nocivos do álcool e, até, melhoria das condições de trabalho. A estrutura de gestão deve trabalhar de modo articulado com os serviços de $\mathrm{SHST}^{7}$ e os sindicatos devem, também, colaborar incidindo a sua acção sobre as consequências a nível da segurança no trabalho (1995). Se a saúde dos trabalhadores interfere na produtividade e na eficácia das empresas, também as condições e os constrangimentos de trabalho interferem na saúde dos trabalhadores, incluindo o equilíbrio psíquico e a saúde mental (Vitória, 1994).

Tomando consciência que o consumo destes psicotrópicos é também uma questão social e que muitas vezes funciona como desinibidor, a empresa também deve actuar a este nível incentivando a outras formas de relacionamento no local de trabalho, orientandoas para a consequente produção (Morel et al, 2001).

O consumo de bebidas alcoólicas encontra-se profundamente enraizado na cultura ocidental em geral e na mediterrânica em particular. Talvez porque as bebidas alcoólicas se encontrem publicitadas ao mesmo tempo que acarretam importantes problemas de saúde (Ruiloba, 2006). Deu-se uma mudança de atitude em relação ao alcoolismo. Deixou de se considerar um vício moral, para se ver como uma doença especial, que tem tratamento e pode ou não chegar à cura, mas que pelo menos pode ser controlada através da abstinência (Gameiro, 1981).

\footnotetext{
${ }^{7}$ Segurança Higiene e Saúde no Trabalho
} 
"Em Portugal, é de bom tom beber com gosto e a contragosto para agradar, para não parecer mal, para fazer companhia, para receber e ser aceite, nas festas e nos lutos, nos banquetes e em jejum. Quem se afasta deste modelo, transgride as tradições, os costumes, o código moral" (Gameiro, 1981:33).

\subsubsection{O tratamento}

O estado de saúde está intimamente ligado aos estilos de vida, deste modo, torna-se necessário sensibilizar as pessoas de modo a que "reduzam os comportamentos que lhe são prejudiciais para a saúde" (2009:4) ${ }^{8}$. É também importante "assegurar que aqueles que fazem escolhas diferentes $e$ adoecem provavelmente em relação a elas, têm o direito de ser tratados e cuidados com todos os recursos disponíveis, no respeito integral pela dignidade da sua condição humana" (2009:4) ${ }^{9}$.

Para que o tratamento se verifique, isto significa que o alcoólico terá que "parar totalmente o consumo de bebidas alcoólicas. Esta paragem não pode ser progressiva, mas imediata" (Sociedade Portuguesa de Alcoologia:15).

Atingida a abstinência, "há medicamentos específicos e eficazes para ajudar o doente a ultrapassar sem sofrimento a síndrome da abstinência daí resultante" (Sociedade Portuguesa de Alcoologia:15).

Este estado pode "trazer riscos para a saúde", por isso torna-se essencial um acompanhamento médico permanente. Para tal, o tratamento pode ocorrer em hospitais ou em clínicas. No entanto, é "possível efectuar este tratamento em regime ambulatório" (Sociedade Portuguesa de Alcoologia:15).

Este tratamento é apenas "uma das etapas no sentido da recuperação". É necessário "aprender a viver sem álcool", pois após instalada a dependência dá-se o impedimento de "voltar a beber mesmo que moderadamente (Sociedade Portuguesa de Alcoologia:15).

\footnotetext{
${ }^{8}$ Autor desconhecido in Revista Dependências http://www.dependencias.pt/images/stories/pdfs/dependencias_fevereiro2009.pdf

${ }^{9}$ Autor desconhecido in Revista Dependências http://www.dependencias.pt/images/stories/pdfs/dependencias_fevereiro2009.pdf
} 
"A emergência da psicologia da saúde veio desafiar a cisão mente-corpo ao propor um papel para a mente, tanto na causa como no tratamento da doença, proporcionando uma visão integral do ser humano" ${ }^{\prime 10}$. Desta forma, surgiu o modelo biopsicossocial que tenta agrupar o modelo biomédico, psicológico e social ${ }^{11}$. Em linhas gerais, aceita-se que o modelo biopsicosocial se caracteriza pelos seguintes aspectos (Gual, 2002):

\section{Abordagem multidisciplinar}

1. A dependência alcoólica define-se como doença crónica com tendência a reincidente.

2. A dependência alcoólica não comporta só problemas físicos, mas também repercussões importantes no âmbito psíquico individual, assim como no campo familiar e sócio laboral.

3. A abordagem terapêutica deve tomar em consideração tanto o indivíduo como a família e o seu meio sócio laboral mais imediato.

4. A reabilitação é um processo de reaprendizagem lento, em que o retorno ocasional às condutas anteriores não é excepcional e deve entender-se como parte integrante do processo de recuperação.

5. O processo terapêutico é realizado pelo paciente. Ao terapeuta corresponde um trabalho de acompanhamento em que a sua missão principal consiste em ajudar o afectado a fazer um bom uso das suas próprias capacidades no processo de reabilitação. A utilização de técnicas motivadoras que provocam a confrontação interna, é muito mais útil neste sentido em que o recurso à confrontação, habitualmente utilizado nos antigos modelos.

\subsubsection{Reabilitação}

A fase da reabilitação tem vários objectivos (Ruiloba, 2006):

a) Que o paciente recupere das sequelas da sua dependência, tanto físicas como psíquicas, familiares e sociais;

\footnotetext{
${ }^{10} \mathrm{http}: / /$ psicologiaclinica.web.simplesnet.pt/Modelo\%20Biomédico\%20versus\%20Modelo\%20Biopsicoss ocial/Modelo\%20biopsicossocial.html

${ }^{11}$ http://psicologiaclinica.web.simplesnet.pt/Modelo\%20Biomédico\%20versus\%20Modelo\%20Biopsicoss ocial/Modelo\%20biopsicossocial.html
} 
b) Que aprenda a levar uma vida satisfatória com a ausência de bebidas alcoólicas;

c) Que adquira consciência da doença e das capacidades necessárias para prevenir recaídas. Para conseguir estes objectivos, deve organizar uma estratégia terapêutica a longo prazo ( 1 a 2 anos) em que será essencial estabelecer uma boa aliança terapêutica e a utilização tanto de recursos farmacológicos como psicoterapêuticos.

“A recuperação é um processo lento, é preciso tempo, para que sejam visíveis as modificações. $O$ alcoolismo é uma doença crónica, por isso a recaída pode surgir em qualquer momento" (Sociedade Portuguesa de Alcoologia:18).

É importante ter em conta que "a recaída não deve ser vista como um insucesso, ou uma fraqueza do indivíduo, mas como um sinal de que as dificuldades ainda não foram totalmente ultrapassadas e que não será a recorrência ao álcool que o fará ultrapassar tais barreiras" (Sociedade Portuguesa de Alcoologia:18).

\subsubsection{O pós-tratamento}

É um erro acreditar que só o tratamento de desintoxicação resolva o problema. "Não constitui senão uma forma de ataque à doença, e favorece ao doente os argumentos que ele vai aprender e servir-se para se defender das ofertas de álcool pelos outros, ou da sua própria tentação de beber" (Sociedade Anti-Alcoólica Portuguesa, 1976:54).

É sabido que em termos físicos já não apresenta dependência alcoólica, encontra-se recuperado ao nível do organismo e melhorado no seu estado físico e psicológico, mas o tratamento não actua ao nível da mudança dos seus hábitos e muito menos ao nível da envolvente social (Sociedade Anti-Alcoólica Portuguesa, 1976).

"Nesta toxicomania que é o alcoolismo, desapareceu o tóxico, mas não desapareceu a mania" (Sociedade Anti-Alcoólica Portuguesa, 1976:54).

É indispensável para o doente "reaprender a viver sem o álcool numa sociedade consumidora do mesmo, produto para qual a sua capacidade de tolerância é absolutamente nula e ficará nula durante toda a sua vida" (Sociedade Anti-Alcoólica Portuguesa, 1976:54).

Para ajudar tanto no tratamento como nas fases posteriores, os grupos de ajuda, são bastante importantes nesta fase, neste caso existem os Alcoólicos Anónimos. "Os grupos estão sempre disponíveis para as pessoas que tenham problemas de álcool, e que procurem quem as oiça e ajude" (Sociedade Portuguesa de Alcoologia:16). 
Com base nas perspectivas teóricas que foram estudadas até aqui foi desenvolvida uma parte prática. Para tal foi necessário recorrer a uma organização que nos permitisse acrescentar conhecimento. É nesta vertente prática que nos iremos centrar de seguida. 


\section{Metodologia}

Para se fazer uma abordagem do alcoolismo nas organizações tendo em consideração um caso real, decidimos estudar uma empresa de transportes aéreos, nomeadamente a TAP. Tal como já tínhamos verificado na revisão literária a UGT refere que trabalhos árduos e a céu aberto, assim como condições pessoais, monotonia, trabalho por turnos, horários desencontrados, trajectos longos e fatigantes (1995), proporcionam o consumo excessivo de álcool. Desta forma, a nossa escolha recaiu sobre a TAP tendo em consideração estes aspectos.

De um modo geral, os estudos de caso são a estratégia preferida quando questões de "como" e "porquê" são postas, quando o investigador tem pouco controlo sobre os eventos, e quando o ênfase se dá sobre o fenómenos contemporâneos dentro de alguns contextos da vida real. Tais como estudos de caso "exploratórios" e "descritivos" (Yin, 1989).

Para a realização deste estudo foi escolhido o estudo de caso, sendo apenas uma das maneiras de fazer pesquisa social científica Yin (1989). Outras maneiras incluem experiências, observações, histórias e a análise de informação arquivada. Segundo Yin, cada estratégia tem vantagens e desvantagens peculiares dependendo de três condições (1989):

- O tipo de questões de pesquisa;

- O controlo que o investigador tem sobre os eventos comportamentais actuais;

- O enfoque no contemporâneo em oposição aos fenómenos históricos.

"O planeamento do estudo de caso envolve (...) a construção de uma abordagem teórica preliminar relacionada com o tópico da investigação a ser estudado" (Barañano, 2004:104).

Há que ter em conta que os métodos se devem adaptar aos objectivos que a investigação possui podendo ser combinados em função das exigências impostas pela concretização dos mesmos (Lima, 1973). 
De modo a recolher a informação, optámos pela entrevista, já que a estrutura da entrevista de pesquisa aproxima-se de uma conversa normal do dia-a-dia, mas uma entrevista profissional envolve uma aproximação específica e uma técnica de questionar (Kvale, 1996).

Há diversos modos de inquirir, e podem variar conforme a sua directividade.

"É habitual reservar o termo entrevista para as técnicas menos directivas e designar por questionário as formas de inquirir em que as questões são formuladas antecipadamente" (Ghiglione e Matalon, 1997:63), embora na prática não exista consenso em relação à limitação destes trâmites (Ghiglione e Matalon, 1997).

Temos por um lado a entrevista não directiva, no decurso da qual é proposto um tema em que a pessoa o desenvolve à sua vontade, sendo que neste caso o papel do entrevistador limita-se a insistências ou encorajamentos, sem acrescentar qualquer nova informação. O questionário fechado, no estremo oposto, é constituído por questões sucessivas, de ordem e formulação fixadas antecipadamente, onde a pessoa inquirida deve responder dentro das alternativas estipuladas, dar a resposta que melhor se adequa (Ghiglione e Matalon, 1997).

Ghiglione e Matalon delimitam uma ordem de dimensão de directividade crescente nos diferentes tipos de técnicas (1997):

1. Entrevista não directiva: o entrevistador propõe um tema e apenas intervém para insistir ou encorajar;

2. A entrevista semi-directiva: (por vezes chamada clínica ou estruturada): o entrevistador conhece todos os temas sobre os quais tem de obter reacções por parte do inquirido, mas a ordem e a forma como os irá introduzir serão deixadas ao seu critério, sendo apenas fixada uma orientação para o início da entrevista;

3. O questionário aberto: a formulação e a ordem das perguntas são fixas, mas o inquirido pode dar uma resposta tão longa quanto desejar e pode ser incitada por insistência do entrevistador;

4. O questionário fechado: a formulação das questões, a sua ordem e a gama de respostas possíveis são previamente fixadas.

Tecnicamente, a pesquisa qualitativa semi-directiva: não é tanto como uma conversa em aberto nem como um questionário extremamente estruturado. É conduzido de acordo 
com um guião de entrevista que se foca em certos temas e que pode incluir questões sugeridas Kvale (1996).

O guião de entrevista permite traduzir objectivos específicos numa linguagem acessível às unidades da amostra; a forma e a ordem das perguntas devem ser cuidadosamente estudadas e ensaiadas mediante um pré-teste (Lima, 1973).

As questões representam as facetas de um domínio empírico que o investigador quer explorar. As questões podem ser gerais ou particulares, descritivas ou explicativas (Miles e Huberman, 1994).

A entrevista de pesquisa é uma situação interpessoal, uma conversa entre duas partes acerca de um tema de mútuo interesse. É uma forma específica de interacção humana na qual o conhecimento evolui através do diálogo (Kvale, 1996).

Dentro dos tipos de entrevista que se podem abordar, optámos pela entrevista semiestruturada ou semi-directiva, pois segue uma sequência de temas a abranger, assim como questões sugeridas (Kvale, 1996). Porém a ordem pela qual os temas podem ser abordados é livre; se o entrevistado não abordar livremente um ou alguns dos temas esquematizados o entrevistador deve propor-lhe o tema (Ghiglione e Matalon, 1997).

É um erro acreditar que os métodos não directivos dão maior liberdade ao entrevistador, além das regras serem bastante limitativas estes métodos recorrem com frequência à opinião do entrevistador, sendo que os riscos neste caso se tornam maiores que nos métodos mais directivos (Ghiglione e Matalon, 1997).

Torna-se "impossível elaborar a concepção geral do estudo sem se determinarem com precisão os fins visados" (Lima, 1973:14).

Os objectivos que foram delineados para este estudo têm como propósito entender como é que dentro de uma empresa se lida com a problemática do Alcoolismo. Deste modo, a nossa entrevista teve como objectivo apurar como é a postura da TAP em relação ao tema do Alcoolismo no contexto empresarial e para tal foi realizado previamente um guião que serviu de apoio para o apuramento de respostas, o mesmo encontra-se anexo (Anexo 1).

Após a escolha da metodologia a seguir, e da mesma ser posta em pratica é necessário tratar a informação que é obtida. O próximo ponto desta dissertação foca-se análise da informação recolhida e tratamento da mesma. 


\section{Tratamento de informação}

Não existe um critério exacto para se proceder à interpretação dos dados, no entanto é importante saber o que se deve fazer a seguir à recolha dos mesmos (Barañano, 2004).

Nesta secção, iremos debruçar-nos sobre o tratamento da informação que foi apurada, para tal há que decidir qual a melhor forma para se efectuar o tratamento. A técnica escolhida foi a análise de conteúdo.

\subsection{Análise de conteúdo}

Para que pudéssemos tratar a entrevista que foi realizada nas instalações da TAP, decidimos usar a análise de conteúdo, sendo que esta é uma técnica de tratamento de informação, e não um método (Vala, 1986).

Os processos de análise e interpretação envolvem um estudo disciplinado, introspecção criativa, e uma atenção cuidada aos propósitos da avaliação (Patton, 1987).

A análise é o processo de dar ordem à informação, organizando o que existe em padrões, categorias e unidades descritivas básicas. A interpretação envolve acrescentar sentido e significância à análise, explicando os padrões descritivos e procurar encontrar relações e conexões entre as dimensões descritivas (Patton, 1987).

Segundo Guerra "a escolha da técnica mais adequada para analisar o material recolhido depende dos objectivos e do estatuto da pesquisa" (2006:63).

Esta técnica de tratamento de dados adequa-se à metodologia usada para a obtenção de informação já que para Gillham a análise de conteúdo assenta na organização substantiva de conteúdos da entrevista: o conteúdo que possui substância (2000).

Esta análise pode integrar-se em qualquer dos procedimentos lógicos de informação empírica, com a vantagem de em muitos casos funcionar como técnica não-osbtrutiva, podendo até incidir sobre o material não estruturado (Vala, 1986).

A análise de conteúdo é "o confronto entre um quadro de referência do investigador e o material empírico recolhido" (Guerra, 2006:62) "e é hoje uma das técnicas mais comuns na investigação empírica realizada pelas diferentes ciências humanas e sociais" (Vala, 1986:101). 
Guerra acrescenta que, "a análise de conteúdo tem uma dimensão descritiva que visa dar conta do que nos foi narrado e uma dimensão interpretativa que decorre das interrogações do analista face a um objecto de estudo, com recurso a um sistema de conceitos teórico-analíticos cuja articulação permite formular as regras de inferência" (2006:62).

O enfoque na análise qualitativa da avaliação dos dados advém de questões geradas no início do processo de avaliação (Patton, 1987). Krippendorff acrescenta que a "análise de conteúdo tem de endereçar questões prioritárias no que diz respeito aos textos disponíveis" (2004:82).

Gillham aponta duas vertentes essenciais para se elaborar a análise de conteúdo:

- Identificar os pontos-chave;

- Colocá-los em categorias.

Bardin defende que antes de se proceder à análise "o material resumido deve ser preparado". Tratando-se "de uma preparação material, eventualmente de uma preparação formal" (2004:94). Sendo que para Patton o primeiro passo é juntar a informação relevante em relação a cada tópico (1987).

Para Gillham (2000) as categorias são simplesmente títulos e o objectivo da construção das mesmas é de ser capaz de assinalar todas as declarações significativas. Sendo que Stevens (1946) considera que "a categorização de unidades de texto é considerada a forma de medida mais elementar" (Citado por Krippendorff, 2004:87).

Este processo de categorização requer que seja um processo exaustivo e exclusivo, neste último aspecto é necessário assegurar que o tipo de afirmações que pertencem a uma categoria não poderiam pertencer também a outra (Gillham, 2000).

Gillham defende ainda que não é possível estudar o conteúdo de uma entrevista sem que se tenha assentado tudo o que ocorreu no seu decurso, incluindo as perguntas adicionais que o entrevistador foi colocando, que de certo modo ajudam a atribuir as subcategorias (2000).

Os dados do caso consistem em toda a informação acerca do mesmo, incluindo toda a informação da entrevista, os dados observáveis, gravações, impressões e declarações de outros acerca do assunto. De um modo geral, consiste em toda a informação que o investigador consegue reunir acerca do assunto que está a estudar (Patton, 1987). 
O processo de desenvolvimento e combinação de categorias é essencialmente acerca da observação dos princípios de exaustão e exclusividade. E ambos os requisitos se tornam impossíveis de serem obtidos a não ser que o investigador tenha desenvolvido a entrevista correctamente (Gillham, 2000).

De facto, esta técnica de tratamento de informação permite que o investigador consiga tratar uma grande quantidade de texto resumindo o seu conteúdo em conjuntos mais pequenos, de forma a ser possível compreender os fenómenos a investigar (Popping, 2000 Citado por Fernandes, 2003:263)

Guerra (2006:63) cita Bardin (1979) quanto à forma como os diferentes tipos de análise de conteúdo se podem agrupar:

- Categorial - Análise temática, que constitui sempre a primeira fase da análise de conteúdo e é geralmente descritiva;

- Avaliação - Mede as atitudes do entrevistado face ao objecto de estudo e a direcção e a intensidade da opinião: desmembra-se o texto em unidades de interpretação (de forma semelhante ao que faz a análise categorial) e analisa-se a carga avaliativa;

- Enunciação - Entende-se a entrevista como um processo. Usa-se sobretudo para entrevistas longas e muito abertas em que se desprezam os aspectos formais de linguagem, centrando-se a análise nos conteúdos;

- Expressão - Análise fundamentalmente formal e linguística utilizada geralmente para investigar a autenticidade de documentos, em psicologia para dar conta do processo de construção das identidades e personalidades ou ainda, em ciência política, para a análise de discursos políticos. 
Krippendorff traduz num esquema a análise de conteúdo qualitativa que se pode ver na figura seguinte:

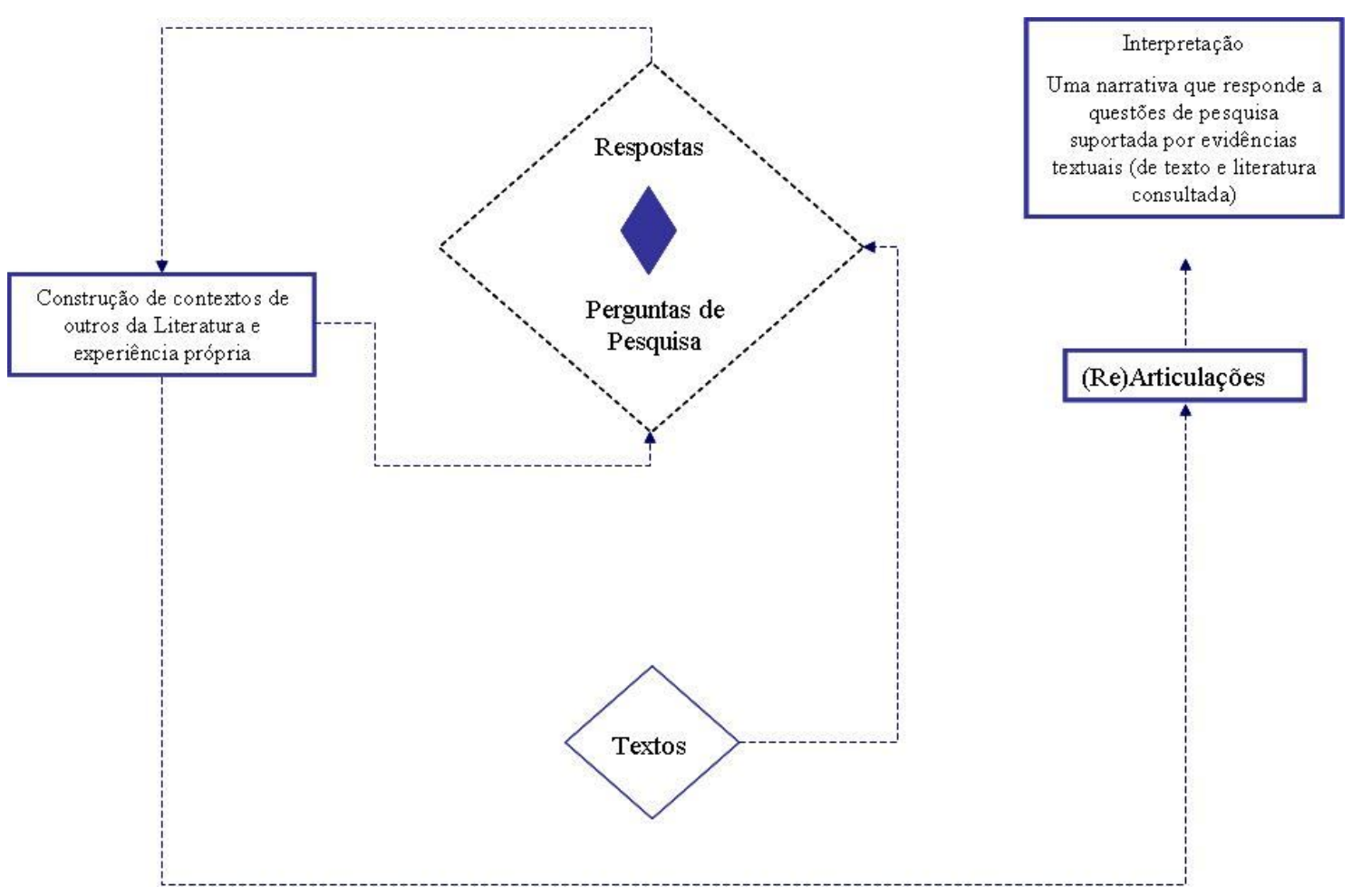

Figura 1 - Esquema de análise de conteúdo qualitativa adaptado de (Krippendorff, 2004)

\subsubsection{Procedimento para a recolha de dados}

Como já foi referido anteriormente recorremos à entrevista semi-directiva para recolher informação junto da TAP.

Antes da entrevista foi introduzido o assunto que se queria desenvolver e explicado o objectivo da realização da mesma.

A entrevista ocorreu nas instalações da empresa e teve a duração aproximada de uma hora tendo sido gravada mediante a autorização das nossas entrevistadas.

As entrevistadas, a Dr. ${ }^{a}$ Maria Olímpia Mourão e a Dr. ${ }^{a}$ Sílvia Baía, ambas assistentes sociais da TAP permitiram que a informação por elas prestadas fosse utilizada no nosso estudo. 
Após a entrevista procedeu-se à transcrição da mesma, tendo sido colocada num ficheiro WORD e posteriormente enviada por e-mail para a Dr. ${ }^{a}$ Maria Olímpia Mourão e a Dr. ${ }^{a}$ Sílvia Baía de modo a que pudessem e verificar se estavam de acordo com o que se encontrava transcrito. Depois de obtida a autorização procedemos à análise da informação obtida, através da análise de conteúdo como se pode verificar no ponto seguinte. 


\subsection{Resultados}

Em seguida iremos proceder ao tratamento da informação que nos foi fornecida durante a entrevista na TAP a duas assistentes sociais da empresa a Dr. ${ }^{a}$ Maria Olímpia Mourão e a Dr. ${ }^{a}$ Sílvia Baía. Para tal usámos a análise de conteúdo para agrupar a informação obtida no decurso da mesma. Os pontos-chave considerados ao longo da análise foram os do alcoolismo, consequências para a saúde, causas do alcoolismo, o diagnóstico, o tratamento e o último ponto a ser tratado é o da reabilitação.

\subsubsection{Alcoolismo}

A problemática do alcoolismo é percepcionada pela TAP, há consciência que o problema existe e ao contrário do que Ouvrad (1996) criticava, o assunto deixou de ser tabu. No entanto as empresas ainda acham que este assunto deve ser tratado muito ao de leve.

Megia e outros (1995) aconselhavam o uso de testes de vestígio de drogas/álcool para promover mais segurança no local de trabalho, assim como eficiência e rentabilidade, no entanto, no caso da TAP é praticada a medicina do trabalho, com análises periódicas e regulares, mas não com o intuito de identificar situações de alcoolismo. Pensa-se até que caso seja detectado álcool no sangue de algum trabalhador não se imagine logo que se poderá encontrar ali um potencial caso de alcoolismo.

Quando se pergunta se os pilotos são sujeitos ao teste de alcoolémia, a realidade é a mesma. Não existe a necessidade de recorrer a estes testes antes da entrada para cada voo. Foi explicado que, como é obvio, a medicina no trabalho nestes casos é praticada com uma maior regularidade que nos outros cargos, no entanto, as assistentes sociais referiram que os pilotos da empresa são muito conscienciosos, daí que nunca tenha existido a necessidade de se efectuar testes antes de voarem. Admite-se que apesar de nunca terem tido conhecimento de alguma situação irregular, o que poderá acontecer é fora do trabalho e caso aconteça em pleno voo a situação encontra-se salvaguardada devido a que colaboram dois elementos no cockpit, e caso um deles não se encontrasse apto, haveria sempre alguém para o substituir na sua função. 
A TAP tem um programa de apoio ao trabalhador que foi implementado " $h a ́$ sensivelmente quinze anos" (Dr. ${ }^{a}$ Maria Olímpia Mourão). Está presente no seu regulamento que está expressamente proibido o consumo de bebidas alcoólicas dentro da empresa (antes, durante ou após o período de trabalho), tal como se pode constatar no ponto 5.1 do Regulamento Interno (Anexo 3). Em consonância com esta regra, deixaram de existir bebidas alcoólicas no refeitório, assim como nas máquinas de venda, realidade que se encontra patente ao longo do ponto 6 do Regulamento Interno da TAP (Anexo 3). Apesar de ser uma regra e de estar implementada, há no entanto maneiras de contornar a situação.

Como não é obrigatório para os trabalhadores almoçarem no refeitório da empresa, não existindo controlo do que é praticado no exterior. Além disso, podem trazer as suas viaturas para dentro da empresa, não existindo fiscalização do que trazem dentro delas, nestes casos, apesar da empresa não deixar de demonstrar que não permite o consumo de álcool nas suas instalações, é muito difícil controlar todo o tipo de esquemas para tornear as regras. É sabido que este problema não pode ser apenas da responsabilidade da empresa e é necessário que haja o bom senso de cada um. Contudo, quem se encontra a trabalhar sob o efeito de álcool, ou recusar efectuar um teste de alcoolemia, poderá estar a incorrer numa infracção disciplinar e estará sujeito ao procedimento correspondente, como se pode verificar no ponto 5.7 do Regulamento Interno da TAP

Quando se fala na hipótese de existência de um protocolo mais rígido, para talvez deixarem de existir tantas possibilidades de fuga ao controlo da empresa, a mesma é posta de parte, a Dr. ${ }^{a}$ Maria Olímpia Mourão considera que "um protocolo mais rígido não seria necessário. Mas que se deveria fazer alguma formação nesse sentido". Da parte do Serviço Social da TAP já se tentou, no entanto, implementar um programa que vai mais ao encontro da formação, talvez para se poder evitar que mais situações de alcoolismo se proporcionem dentro da empresa. Contudo a empresa defende no seu Regulamento Interno no ponto 8.1 (Anexo 3) que deverá promover acções de formação e informação do pessoal, com o intuito de "prevenção e diminuição da incidência do consumo de álcool". 
Quando interrogadas acerca da possível causa da não implementação do programa poder ocorrer por receio de que no exterior julguem que os casos de alcoolismo na TAP sejam demasiados, a resposta é negativa. Para as assistentes sociais essa é uma realidade que não se enquadra nas empresas dos dias de hoje, pois é conhecido por toda a gente que os casos de alcoolismo existem em contextos empresariais. Foram inclusivamente apontados, a título de exemplo, os casos da $\mathrm{CP}^{12}$ e da Carris que já implementaram programas neste âmbito, "estamos portanto a falar das empresas de transporte em geral" (Dr. " Sílvia Baía). Pondera-se então que a TAP não encontre justificação suficiente para actuar de outra forma e não por existir receio do que se poderá pensar externamente.

No entanto, é importante referir que a empresa apesar de não ter um protocolo virado exclusivamente para a detecção e tratamento do alcoolismo, não deixa de acompanhar estas situações, antes pelo contrário. O processo de detecção pode é não ser tão célere como no caso de existir um programa formal elaborado única e exclusivamente para esse efeito, no âmbito do apoio ao trabalhador, até porque as situações vão surgindo um pouco soltas. Mas existe de facto um esquema delineado e as pessoas não deixam de ser encaminhadas e tratadas quando os seus casos surgem. Talvez ainda não tenha existido hipótese de implementar o programa que já se encontra elaborado, porque os casos vão tendo sempre respostas e são acontecimentos pontuais, sendo que a empresa percepciona que a situação está controlada e talvez, por isso considere que não existe justificação para agir de outra maneira.

\subsubsection{Consequências para a saúde}

Como se pode verificar no Regulamento Interno da TAP em relação à prevenção e controlo do consumo de álcool, drogas e tabaco (Anexo 3) a empresa mostra ser consciente em relação às consequências que o consumo de álcool e drogas pode trazer para os indivíduos e tal como refere devido à sua gravidade estas não podem ser ignoradas.

Os efeitos podem sentir-se em diferentes níveis:

- Funções fisiológicas: hepáticas, digestivas e cardiovasculares;

\footnotetext{
${ }^{12}$ Caminhos de Ferro Portugueses
} 
- Aptidões sensório-motoras: entre elas encontram-se os "reflexos no tempo de reacção, motricidade, visão, execução de tarefas de vigilância";

- Funções cognitivas: ao "nível da apreensão, decisão, aprendizagem e outras de natureza intelectual e emocional".

Alguns destes efeitos são apontados por Gameiro (1981).

Tal como é referido no Regulamento Interno no ponto I Exposição de motivos (Anexo 3), estes efeitos geram consequências negativas para ambas as partes, empresa e trabalhadores, tanto para o próprio indivíduo quanto para os seus colegas de trabalho. A TAP aponta as consequências para cada um destes casos.

\section{- Consequências para o trabalhador:}

"Alterações físicas, de carácter e de comportamento, estas podem ser verificadas através de ausência, náuseas, tremor das mãos, tendência para o isolamento".

Os problemas físicos e psíquicos têm tendência a agravar-se "caracterizando-se por comportamentos agressivos, nervosismo e irritabilidade".

Ao nível da capacidade de decisão e raciocínio também se encontram alterações. Perca progressiva de auto-estima, indiferença em relação ao ambiente de trabalho, diminuição de zelo e diligência, falta de pontualidade e assiduidade que proporcionam em conjunto uma redução significativa de produtividade corroborando a teoria de Megia et al. (1995).

Podem ocorrer acidentes que podem provocar ferimentos, incapacidades ou até morte.

\section{- Consequências para os colegas de trabalho:}

Ao nível do trabalho de equipa, que é "próprio da empresa e quase sempre indispensável, uma falha de algum dos membros afecta" a dinâmica do grupo, sendo que têm um impacto directo no esforço e produtividade. 
Acontecem também problemas ao nível de "reclamações, conflitos pessoais, deficiência na execução das tarefas, agravamento dos riscos de acidentes laborais e quebra na produtividade", pois os colegas que a princípio tentam suprir as lacunas deixadas pelo indivíduo com problemas, a princípio é suportável, mas deixa de o ser rapidamente. Num sentido extremo este descontentamento dos colegas podem conduzir a que outros sigam os passos do trabalhador prevaricador.

\section{- Consequências para a empresa:}

As consequências para a empresa são também elas negativas ao nível do aumento com os "encargos médicos, dos prémios de seguros, absentismo, redução da produção, danos materiais, pagamento de indemnizações, deterioração da imagem dos trabalhadores e da própria empresa".

Devido à instabilidade que proporcionam os trabalhadores com consumos abusivos, conduzem a substituições constantes, seja temporária ou definitiva. Estas modificações nos quadros da empresa além de terem impacto nos custos directos, também se traduzem numa perda de conhecimentos profissionais e experiência, e acabam por ser também custos para empresa, dado que a sua aquisição envolveu montantes significativos.

\subsubsection{Causas do alcoolismo}

Torna-se difícil à partida atribuir as causas que poderão contribuir para o consumo excessivo de álcool. Estas variam de pessoa para pessoa e claro que existem vários factores envolventes a ter em conta.

A primeira noção que surge quando esta questão é colocada, no caso da TAP, é que a maior parte dos casos reside nas faixas etárias mais novas.

As causas referidas encontram-se assentes nos estilos de vida e nos problemas familiares que se possam sentir. Assim como são identificadas causas ao nível interno, ao nível profissional. Admite-se que poderão ser identificadas como possíveis causas o stress causado pelo trabalho, o cansaço que a própria pessoa sente ao desempenhar alguma função, assim como a desmotivação do indivíduo. 
É inclusive referido que também poderão existir algumas pessoas que podem já ter alguma tendência a praticar este tipo de comportamento, podem ter uma certa propensão para tal.

Foi também referido que têm igualmente a ver com os hábitos de vida que cada um vai criando, e com os grupos em que estão inseridos, o que corrobora com a afirmação de Morel e outros (2001) consideram que o consumo de certas substâncias vem reforçar o sentimento de pertença ao grupo.

\subsubsection{Diagnóstico}

Tal como já foi referido a TAP não possui um programa direccionado exclusivamente para a prevenção e detecção de casos de alcoolismo, mas de qualquer forma os casos existem e são percepcionados de formas diferentes e em estados também eles distintos.

Segundo o Regulamento Interno da TAP a detecção dos casos de Alcoolismo compete fundamentalmente aos serviços de medicina, saúde, higiene e segurança no trabalho.

Existem casos que nunca chegam a passar pelo Serviço Social da TAP ou até mesmo pela $\mathrm{UCS}^{13}$, pois há quem consiga disfarçar o seu comportamento de modo a que ninguém se aperceba e os que decidem procurar ajuda, fazem-no normalmente no exterior, daí que seja complicado para a empresa tomar consciência da plenitude da problemática. Normalmente, as pessoas que procuram ajuda fora da TAP, fazem-no porque sendo este um contexto empresarial, podem sentir receio de algumas retaliações ou até preferir que o assunto nunca chegue a ser conhecido, talvez por vergonha e embaraço, ou até porque achem que poderá não ser tratado com confidencialidade, no entanto, quem pensa desta forma encontra-se equivocado pois a TAP faz questão de frisar que preza a confidencialidade dos seus trabalhadores, como se pode verificar no ponto 5, alínea b) do Código de Ética da TAP (Anexo 2). Realidade que é sublinhada pelas assistentes sociais, pois afirmam fazer parte da sua ética profissional salvaguardar os interesses dos trabalhadores e que por isso mesmo os assuntos são tratados na base da confidencialidade e acrescentam que só serão incluídas no processo as pessoas estritamente necessárias, mediante o consentimento do indivíduo.

\footnotetext{
${ }^{13}$ UCS - Unidade de Cuidados de Saúde, a fundada pela TAP em 1995
} 
Neste processo terá então sentido pôr a par da situação as chefias pois terão de prestar uma atenção especial à situação, no entanto há casos onde outras pessoas que estão próximas podem aperceberem-se do que se passa. Aliás é esta uma das formas pela qual o Serviço Social toma conhecimento das situações de comportamentos irregulares. Tal como foi referido, às vezes só se torna possível tomar consciência dessas situações quando os próprios colegas ou as chefias, reparam que os comportamentos da pessoa poderão ser estranhos talvez pelo consumo excessivo de álcool e nessa altura, numa perspectiva de ajuda, dirigem-se ou aos Serviços Sociais ou pela vertente clínica é contactada a UCS.

Claro que ainda mais importante é quando a própria pessoa sente que tem um problema e se dirige ela própria à empresa, seja pela parte social ou clínica e pede ajuda.

Esses casos na TAP também existem, e quando acontecem as pessoas são imediatamente ajudadas e encaminhadas para seguirem com o seu tratamento.

Há ainda a possibilidade da família ser ouvida, e ser alguém da mesma que entre em contacto com a empresa a pedir ajuda. A Dr. ${ }^{a}$ Sílvia Baía refere que "articulamos com a família sempre que se justifique, e faz sentido fazê-lo" a Dr. ${ }^{a}$ Maria Olímpia Mourão acrescenta que "somos o elo de ligação". Esta abertura da empresa para com a família é bastante importante e tem um maior impacto no tratamento tal como aponta a UGT (1995). Infelizmente, por parte dos serviços sociais, é revelada uma realidade que aponta a existência casos onde as pessoas não têm força de vontade nenhuma para ultrapassar os seus problemas ou até apoio familiar. Nestas situações o papel deste serviço é bastante importante para ajudar a pessoa que não tem aparentemente motivações para sair da situação complicada onde se encontra. Os serviços sociais tentam rodear estas questões, falar com os médicos no trabalho e em conjunto tentam encaminhar a situação.

\subsubsection{Tratamento}

Em relação ao tratamento aplicado aos trabalhadores, tal como já foi percepcionado quando tratámos a parte do diagnóstico, depende muito da maneira como e quando a situação é percepcionada. 
A TAP assegura no seu Regulamento Interno no ponto 5.10 (Anexo 3) "que para efeitos de tratamento adequado, poderá privilegiar o encaminhamento do trabalhador para a situação de incapacidade temporária por doença a cargo da Segurança Social, sem prejuízo do acompanhamento no âmbito da empresa".

Quando as pessoas optam por procurar tratamento no exterior, os assuntos já não passam pela empresa, portanto não existe acesso a esses acontecimentos.

Quando a situação passa pelo conhecimento da empresa, há diferentes formas de acção, que variam conforme o estado em que a situação de alcoolismo se encontra. Existindo apenas a necessidade de acompanhamento ao nível psicológico e de tratamento que não necessita de internamento, as situações são encaminhadas para a Unidade de Cuidados de Saúde. No caso de ser necessário proceder ao internamento os trabalhadores são encaminhados para instituições fora da empresa sendo que estas podem ser públicas ou privadas. Existindo a possibilidade de tempo de espera, a pessoa é encaminhada para o sector público, nomeadamente o $\mathrm{CRAL}^{14}$, no entanto, em casos de maior gravidade, o tempo de espera não é um factor que se possa ter em conta, há então que encaminhar para o sector privado. As pessoas podem ser aconselhadas a ir para algumas instituições ou então poderão ir para "clínicas que ouviram falar". Por parte dos Serviços Sociais algumas instituições privadas que costumam ser apontadas são o Farol $^{15}$, São Fiel ${ }^{16}$ e o CRATO $^{17}$. Claro que a possibilidade de ir para o público ou privado também depende da decisão da própria pessoa. Nesta decisão há também que ter em conta, o factor financeiro. Quando indagadas sobre a possibilidade da empresa poder ajudar financeiramente no caso da pessoa necessitar de tratamento no sector privado, as assistentes sociais referiram que apesar de não existir uma comparticipação da empresa nessa situação é posta à disponibilidade um empréstimo sem juros e sempre reembolsável.

\footnotetext{
${ }^{14}$ CRAL - Centro Regional de Alcoologia de Lisboa que pertence ao CRAS - Centro Regional de Alcoologia do Sul

15 Associação para o tratamento de toxicodependências a funcionar em Sintra

${ }^{16}$ A funcionar em Castelo Branco

${ }^{17}$ CRATO - Centro de Recuperação do Alcoolismo e Toxicodependência a funcionar no Porto
} 
A actuação desta empresa vai contra o programa de detecção e acção sobre os trabalhadores alcoólicos que Gameiro (1983) indicou ser posto em prática por duas empresas há algumas décadas, como se pode verificar na parte teórica do trabalho. Este programa indica que "é a empresa através da seguradora, que suporta todas as despesas de consultas e tratamento em centro adequado até quatro semanas". Apesar da empresa se mostrar disposta a ajudar quando este tipo de situações ocorrem, em termos financeiros a situação não está contemplada pelo programa de apoio ao trabalhador.

\subsubsection{Reabilitação}

Em termos empresariais não se consegue ter noção na plenitude dos factores que costumam surgir após a fase do tratamento do trabalhador, nomeadamente os que Ruiloba (2006) aponta como objectivos da fase de reabilitação. É sentido pela empresa que há necessidade de prestar uma atenção especial aos trabalhadores que regressam do tratamento. Tem de existir por parte das chefias uma atenção redobrada, de maneira a poder ajudar nesta fase que ainda é muito difícil para o trabalhador. É nesta etapa que a ajuda por parte dos colegas mais próximos deverá ser sentida. 
Há também que ter em conta se a pessoa após o regresso do tratamento volta ao mesmo posto de trabalho ou não, isto porque voltando a referir Morel (2001), este comportamento pode reforçar o sentimento de pertença ao grupo, e se o comportamento de excessos for partilhado pelo grupo de trabalho de onde a pessoa foi retirada, poderá haver um retrocesso na sua recuperação. Colocada a questão sobre a possibilidade do trabalhador regressar ao mesmo posto de trabalho, as respostas foram consonantes, nesta situação não há apenas uma decisão que se possa tomar, depende sempre muito. A Dr. ${ }^{a}$ Maria Olímpia Mourão responde que o trabalhador "voltava ao mesmo posto ou não, conforme a situação". Tal decisão varia com a função que a pessoa desempenha, nomeadamente se se trata de um cargo que lida mais com "áreas operacionais ou com o contacto com o público"(Dr. a Sílvia Baía). Estas áreas são mais sensíveis a este tipo de situações, ou seja, há que ter mais cuidado quando se trabalha directamente com o público e uma atenção redobrada quando a função passa pela área operacional, daí que nesta situação seja necessário pesar estes factores. Mediante a avaliação que se fizer, tomar-se-á a decisão de manter ou mudar de posição o trabalhador na estrutura da empresa. Há também a ter em conta há quanto tempo o problema já existe, qual o estado de recuperação do indivíduo dependendo sempre da envolvente e em geral de todo o meio onde o trabalhador está inserido.

A situação do trabalhador é analisada antes da pessoa ser integrada. As avaliações psicológicas ficam a cargo da instituição onde se deu o acompanhamento. 


\section{Conclusões}

Esta dissertação tinha como finalidade estudar a problemática do Alcoolismo no contexto empresarial tendo em consideração o estudo do caso da TAP.

O nosso objectivo era perceber como é que é percepcionado e tratado o problema do Alcoolismo num contexto real.

Através do estudo de caso foi possível recolher a informação necessária para ser analisada, e o seu tratamento foi realizado através da análise de conteúdo.

Neste estudo conseguimos apurar que o Alcoolismo deixou de ser um assunto considerado tabu em contexto empresarial sendo percepcionado como um problema sobre o qual se deve agir. A TAP além de percepcionar a sua existência assume que o problema existe na sua organização.

A TAP trata esta problemática à luz do Programa de Apoio ao Trabalhador, praticando a medicina no trabalho, sendo que não possui um programa delineado única $\mathrm{e}$ exclusivamente para a prevenção e detecção de casos de alcoolismo. No entanto faz parte do seu Regulamento Interno de Prevenção e Controlo do Consumo de Álcool, Drogas e Tabaco a proibição do consumo de bebidas alcoólicas nas suas instalações. Apesar de não existir um programa direccionado para o alcoolismo, isso não significa que os casos não tenham um acompanhamento e que as situações não se encontrem controladas, isto leva-nos a concluir que talvez seja por isso que não sentem a necessidade de optar por outro tipo de protocolos.

A empresa tem consciência das consequências adversas do Alcoolismo. Sendo que as consequências deste tipo de comportamentos podem ser da ordem fisiológica, sensóriomotora, ou cognitiva. No entanto apesar do indivíduo sofrer com os efeitos negativos do seu vício, há também a ter em consideração os danos que este causa à empresa e aos colegas de trabalho, assim como ao próprio indivíduo como parte da dinâmica do grupo. Conclui-se portanto, que quando existem casos de Alcoolismo numa organização, sofrem todos danos, directa ou indirectamente e não apenas o indivíduo adicto.

As causas apontadas como geradoras de comportamentos do consumo abusivo de álcool, assentam nos estilos de vida, problemas familiares e problemas relativos ao trabalho, tais como stress, cansaço e a desmotivação sentida. Sendo que os hábitos de vida ou grupos onde se inserem são também apontados. 
Verifica-se também que associado às causas que podem estar por detrás dos comportamentos abusivos de consumo de álcool, podem relacionar-se positiva ou negativamente com a procura de efeitos secundários do álcool, ou seja, quem bebe por ter problemas familiares ou desmotivação, talvez procure na bebida aquele que foi identificado como o lado mais depressivo, e deste modo os efeitos inibidores do álcool. Por outro lado, quando tem a ver de certa forma com os grupos em que os indivíduos estão inseridos, e sendo maioritariamente pessoas novas, tendo também em consideração a sociedade em que vivemos, talvez possamos dizer que as pessoas nestes casos procuram os efeitos estimulantes que o álcool oferece.

No que diz respeito ao diagnóstico verifica-se que os casos de alcoolismo podem ser identificados pelas chefias, colegas de trabalho, família ou até ser o indivíduo que pede ajuda assumindo que tem um problema. Após identificada a situação, o tratamento pode ocorrer dentro da empresa, caso não exista a necessidade de recorrer a internamento. Caso seja necessário, este ocorre no exterior, podendo ocorrer pela via pública ou privada. Pelo público o tempo de espera é um factor a ter em conta, por outro lado, o privado acarreta uma disponibilidade económica. Caso a via escolhida seja a privada, a TAP apenas apoia financeiramente sob a forma de empréstimos reembolsáveis sem juros.

Efectuado o tratamento, é realizada uma avaliação da situação do trabalhador antes de este ser colocado no mesmo posto, pois há que assegurar que a sua situação não irá interferir com o cargo ocupado.

É também importante assegurar que o indivíduo é apoiado e existe sobre ele uma atenção e apoio redobrados.

Seria expectável que, uma empresa como a TAP, tendo um número elevado de colaboradores e devido às funções que os mesmos desempenham deveria possuir um programa centrado no Alcoolismo na vertente da prevenção e formação. Se tal fosse praticado, poderia existir um diagnóstico, ou uma detecção mais célere, e as situações acompanhadas numa mais fase inicial. 


\subsection{Limitações e sugestões para futuras investigações}

Segundo Yin (1989) quando se estuda apenas um caso, existem limitações em relação à possibilidade de generalizar as conclusões em estudo. Este estudo apresenta esta limitação pois apenas foi retratado o caso da TAP. Sendo por isso prematuro tentar generalizar as conclusões a que chegámos. Contudo, tal como foi definido, este trabalho tinha por objectivo apenas tentar perceber como se processava a realidade numa empresa, de modo a dar continuidade à teoria estudada.

Durante este estudo ficou muito ainda por apurar, no entanto algo que poderia ser interessante para se investigar seria tentar perceber de que forma interferem os grupos na tomada de decisão do indivíduo relativamente a esta problemática e desta forma de que maneira se devem colocar os reabilitados numa organização após o tratamento, de modo a que os comportamentos outrora partilhados em grupo não continuem a acontecer. 


\section{Bibliografia}

Barañano, A. (2004) - Métodos e Técnicas de Investigação em Gestão, Lisboa: Edições Sílabo, Lda, 102-109

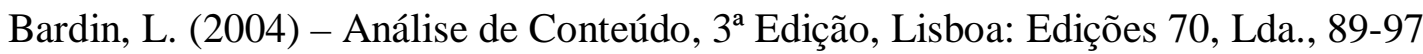

Castelão, M. O. et al. (1987) - Abordagem Sócio-económica da problemática do consumo excessivo do álcool em Portugal. Sociedade, Saúde e Economia: Actas da V Jornadas de Economia e saúde. Portugal: Escola Nacional de Saúde Pública, 395-410

Cherrington, D. J. (1995) - The Managment of Human Resources. Engleewood Clifs: Prentice-Hall, 625-657

Chiavenato, I. (1993) - Recursos Humanos: Edição compacta. 2a Edição. São Paulo: Editora Atlas, SA, 353-374

Fernandes, A. (2003) - Tipologia da Aprendizagem Organizacional: teorizações e estudos, Tese de Doutoramento em Gestão, ISCTE, 258-261

Gameiro, A. (1981) - Alcoolismo na interacção sistémica: aspectos psicossociais da alcooldependência. Mem Martins: Revista Hospitalidade, 23-35; 46-48; 64-78

Gameiro, A. (1983) - Álcool, alcoolismo e drogodependência: recuperação através da reestruturação interrelacional e sistémica. Mem Martins: Revista Hospitalidade, 38-41

Ghiglione, R., Matalon, B. (1997) - O Inquérito: Teoria e Prática. $3^{\text {a }}$ Edição. Oeiras: Celta Editora, 63-91

Gillham, B. (2000) - The research Interview, London: Continuum, 59-72

Gual, A. (2002) Alcoolismo em Ruiloba J. V. (Ed.) (2006) - Introducción a la psicopatologia y la psiquiatria. $6^{a}$ Edição. Madrid: ELSEVIER, 591-596, 599-613

Guerra, I. (2006) - Pesquisa Qualitativa e Análise de Conteúdo, Estoril: Principia Editora, Lda., 61-72

Institut Suisse de Prévention de L'Alcoolisme et Autres Toxicomanies (1993) - O Alcoolismo na Família, Sociedade Portuguesa de Alcoolismo (Ed.), Porto: Sociedade Portuguesa de Alcoologia, 1-17

Krippendorff, K. (2004) - Content analysis: An introduction to its methodology, $2^{\mathrm{a}}$ Edição, Thousand Oaks: Sage Publications, 81-95

Kvale, S. (1996) - InterViews: An Introduction to Qualitative Research Interviewing. Thousand Oaks : Sage Publications, 88-143

Lima, M. P. (1973) - O inquérito sociológico: problemas de metodologia. Lisboa: Cadernos-Gis, 12-31

Manual de Segurança Higiene e Segurança no Trabalho (1995) Lisboa: UGT, 440-448

Megia., L. et al. (1995) - Managing Human Resources. Englewood Cliffs: Prentice Hall International, 580-589 
Milan, J. e K. Kethan. (1986) - Alcoolismo: os mitos e a realidade. São Paulo: Nobel, $129-132$

Milles, M. B., Huberman, A. M. (1994) - Qualitative Data Analysis. 2a Edição. Thousand Oaks: Sage Publications, 16-38

Morel, A. et al. (2001) - Prevenção das toxicomanias. Lisboa: Climepsi Editores, 275282

Ouvrard, C. (1995) - O Alcoolismo na Empresa: a Conspiração do silêncio. Revista Dirigir N. ${ }^{\circ} 35,36-38$

Patton, M. (1987) - How to use Qualitative Methods in Evaluation, Newbury Park:

Sage Publications, 144-147

Ruiloba J. V. (2006) - Introducción a la psicopatologia y la psiquiatria. 6 $6^{\text {a }}$ Edição. Madrid: ELSEVIER, 591-596, 599-613

Sociedade Anti-Alcóolica Portuguesa (1976) - Generalidades sobre o Alcoolismo, 3356

Vala, J. em Silva, A., Pinto, J. (Ed.) (2005) Metodologia das Ciências Sociais, 13 ${ }^{\mathrm{a}}$ Edição, Porto: Edições Afrontamento, 101-115

Velleman, R. (2001) - Counselling for Alcohol Problems. 2a Edição, Londres: Sage

Vitória, P. (1994) - Consumo de álcool e drogas ilegais em empresas do distrito de Lisboa, Cascais: Fundação Portuguesa para o Estudo, Prevenção e Tratamento da Toxicodependência

Yin, R. (1989) - Case Study Research: Design and Methods. Newbury Park: Sage Publications, 18-27

\section{Sites consultados}

Psicologia Clínica (27 de Maio de 2009)

http://psicologiaclinica.web.simplesnet.pt/Modelo\%20Biomédico\%20versus\%20Model o\%20Biopsicossocial/Modelo\%20biopsicossocial.html

Revista Dependências Fevereiro de 2009, http://www.dependencias.pt/images/stories/pdfs/dependencias_fevereiro2009.pdf TAP - Transportes Aéreos Portugueses www.tap.pt 


\section{Anexos}


Anexo 1 - Guião de entrevista

No âmbito da Higiene e Segurança no trabalho, visualizámos a necessidade de explorar a problemática do Alcoolismo nas organizações, sendo que é algo que afecta cada vez mais as empresas dos dias de hoje.

Esta entrevista tem como objectivo perceber qual a postura da TAP em relação a este cenário da actualidade. 


\section{Apoio ao trabalhador}

i. No caso da TAP, é sentido por parte dos trabalhadores que há um organismo que põe em prática um plano de apoio ao trabalhador e que eles estão protegidos pela existência do mesmo? (verificar se existe a divulgação dentro da comunidade)

ii. Caso seja percepcionado pelos mesmos, existe a noção de confidencialidade? Qual a importância que julga que esse factor acarreta? (procurar perceber se os trabalhadores não procuram o apoio da empresa por medo de represálias por parte dos colegas dentro da comunidade)

iii. Existem regulamentações com o intuito de interditar a pratica de alguns actos dentro da comunidade da TAP? Quais? (por exemplo a proibição de vendas entre trabalhadores, praticas de jogo, ingestão de bebidas alcoólicas)

\section{Alcoolismo (problemática)}

iv. Qual é o comportamento da empresa em relação ao alcoolismo? (verificar se há a percepção de uma participação activa)

v. Que tipo de prevenção é feita? (procurar saber se há a preocupação por parte da empresa especificamente direccionado ao alcoolismo)

\section{Detecção}

vi. Como é que é identificado um trabalhador com problemas alcoólicos? (perceber de que modo a hierarquia actua neste processo)

vii. Qual o papel da família do trabalhador neste processo? (perceber se a família é contactada durante este processo. Verificar se há a necessidade de procurar saber de que forma ela se encontra afectada pela situação e como conseguir ajudá-la)

viii. Poderá ser a família a chamar a atenção sobre o problema do trabalhador? (tentar perceber se a mesma tem um papel activo e se é ouvida pela entidade que actua ao nível da higiene e segurança)

\section{Tratamento}

ix. Como se processa o tratamento? (que etapas percorre) 
X. É feito interna ou externamente? (há meios do mesmo ser realizado dentro da empresa ou se existe a necessidade de recorrer a outras instituições)

xi. Qual a duração do mesmo?

xii. Qual é a percentagem de sucesso?

\section{Reabilitação}

xiii. Na fase de reabilitação o trabalhador é de alguma forma apoiado por parte da empresa? (monetária e psicologicamente)

\section{Pós-tratamento}

xiv. Quais são as hipóteses que lhe são dados após o tratamento? (tem a ver com o facto de poder existir por parte do trabalhado um compromisso de recuperação, não tendo a empresa a obrigatoriedade de agir diversas vezes sobre o mesmo problema)

Xv. Quando o trabalhador regressa é inserido no mesmo posto de trabalho, com as mesmas funções? (percepcionar se existe a consciência de que a inserção no mesmo ambiente onde ocorreu o problema nem sempre ajuda na fase de recuperação)

\section{Consciencialização}

xvi. Quais, na vossa opinião, são as razões que levam o trabalhador ao consumo excessivo de álcool? (perceber se apenas têm em conta os aspectos pessoais ou também invocam os profissionais)

xvii. Qual o papel que pensam que a empresa deve desempenhar? 
Anexo 2 - Código de Ética da TAP
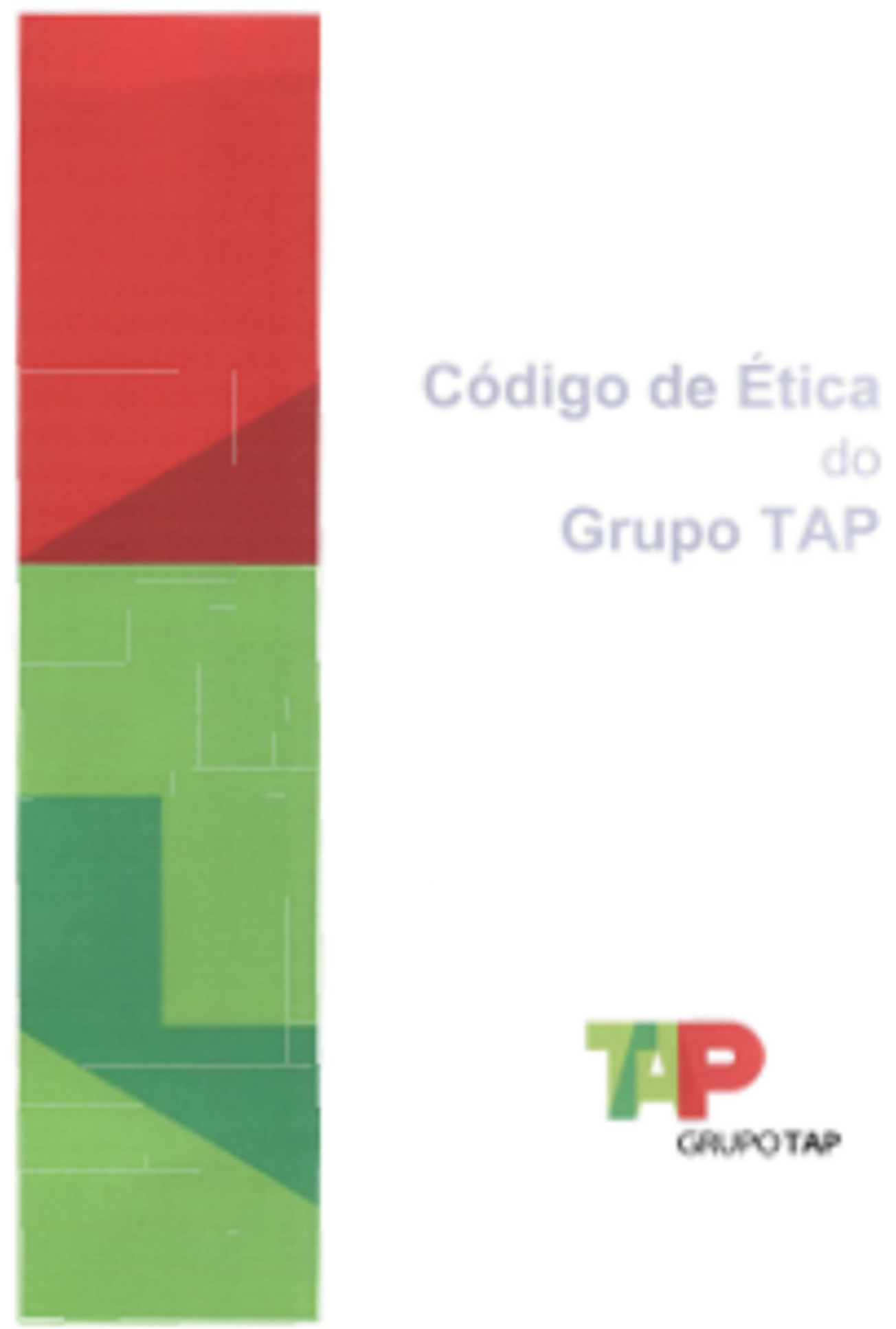


\section{ÍNDICE}

Objectivos e Valores Fundamentais........................ 2

I. Âmbito …....................................................... 3

II. Valores Gerais......................................... 3

1. Responsabilidade................................. 3

2. Independência..................................... 3

3. Conflitos de Interesses........................ 3

4. Desenvolvimento Profissional.............. 4

5. Confidencialidade.............................. 4

III. Deveres Especiais.................................. 5

1. Relacionamento com o Mercado........... 5

2. Relacionamento com o Cliente............. 5

3. Relacionamento com Concorrentes..... 5

4. Relacionamento com Fornecedores..... 6

5. Relacionamento com Colaboradores.... 6

6. Relacionamento Interpessoal............. 7

7. Protecção de Direitos Pessoais............... 8

8. Segurança e Bem-Estar no local de Trabalho.............................................. 8

9. Uso de bens da Empresa...................... 9

10. Ambiente.......................................... 9

11. Responsabilidade Social.................... 10

Aprovação e assinatura ......................................... 11 


\section{Objectivos e Valores Fundamentais}

GRUPOTAP

O Grupo TAP tem como foco da sua actividade a prestação de serviço de Transporte Aéreo e actividades afins. Está presente em quase todos os Continentes e insere-se numa actividade económica que ocupa uma parte muito significativa da população activa e das economias desenvolvidas e globalizadas, contribuindo para a criação de riqueza e também para a aproximaçăo dos povos e culturas.

Empenhado na realização da sua vocação, a TAP definiu como seus objectivos essenciais afirmar-se como uma das empresas mais desejadas para:

- Voar, satisfazendo os seus clientes com elevados padrões de qualidade.

- Trabalhar, valorizando os seus colaboradores nas valências pessoais e profissionais.

- Investir, procurando o melhor retorno dos investimentos e remunerando adequadamente os seus accionistas.

A TAP pauta a sua acção por critérios de excelência e empenhamento com a comunidade, associando-se a iniciativas que promovem os valores da ética como fundamento da gestão e cultura empresarial, pelo que assume também como seus objectivos:

- Praticar os mais elevados valores de ética e integridade pessoal;

- Respeitar a qualidade de vida das comunidades em que está integrada. 
O Código de Ética aplica-se a todas as pessoas que trabalham nas empresas do Grupo TAP, qualquer que seja o seu vínculo laboral ou mandato em corpos sociais executivos ou não executivos das empresas que o constituem, de ora em diante designados por "colaboradores do Grupo TAP".

\section{II - VALORES GERAIS}

1. Responsabilidade

Os colaboradores do Grupo TAP são responsáveis perante as respectivas chefias ou órgãos sociais competentes e estes perante os respectivos accionistas, pelo respeito e cumprimento dos valores e principios consignados no Código de Ética.

\section{Independência}

Os interesses do grupo devem ser os únicos a serem tomados em conta em todas as relaçōes com terceiros, respeitando e assumindo os valores da seriedade e imparcialidade.

\section{Conflitos de Interesses}

a) Os colaboradores e os membros dos Órgãos Sociais do Grupo TAP não podem envolver-se em qualquer actividade que seja contrária ao interesse empresarial do Grupo, prejudique a reputação das Empresas ou a sua relação com terceiros, ou interfira com as suas responsabilidades como colaborador ou membro de Órgão Social.

b) Os colaboradores e os membros dos Órgãos Sociais não podem concorrer contra as Empresas do Grupo ou usar a sua posição, influência, informação, activos ou recursos para beneficio indevido do próprio ou de terceiros. 
c) Os colaboradores e membros dos Órgãos Sociais não podem usar para beneficio próprio oportunidades descobertas através de activos, informação ou posição nas Empresas do Grupo TAP.

d) Sempre que no exercício da sua actividade qualquer colaborador tenha de intervir em processos de decisão ou tome conhecimento de processos que de algum modo envolvam interesses reais ou pessoais relativamente a si próprio ou a alguém do seu agregado familiar, deve adoptar as medidas necessárias para o evitar, ou, não sendo possivel, comunicar às respectivas chefias ou ao Órgão Social que o elegeu.

\section{Desenvolvimento Profissional}

Os colaboradores do Grupo TAP devem ao longo da sua vida profissional na Empresa dedicar o melhor do seu empenhamento no cumprimento das tarefas que lhe forem confiadas e procurar sempre aperfeiçoar e actualizar os seus conhecimentos.

\section{Confidencialidade}

a) Os colaboradores do Grupo TAP devem guardar sigilo em relação a todos os factos respeitantes à vida da Empresa e de que tenham conhecimento no âmbito das suas funções ou por causa delas

b) As informaçōes pessoais sobre os colaboradores estāo sujeitas. ao principio daconfidencialidade, sendo a sua utilização restrita ao próprio e ao pessoal responsável pela guarda, manutenção e tratamento dessas informações. 


\section{III - DEVERES ESPECIAIS}

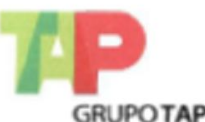

1. Relacionamento com o Mercado

As empresas do Grupo TAP actuarāo no mercado de forma transparente e em leal concorrência, visando a maior eficiência das transacções e a satisfação dos clientes.

2. Relacionamento com o Cliente

As empresas do Grupo TAP manterāo com os seus clientes uma relação transparente baseada nos principios de:

a) Informação correcta e completa sobre os serviços que prestam;

b) Utilização de práticas comerciais que respeitem a liberdade de escolha do cliente;

c) Adopção de mensagens publicitárias que respeitem os principios de correcção, de identificação e de verdade, na estrita observância dos direitos de terceiros;

d) Manutenção de serviços de reclamações eficazes na resposta às solicitações dos clientes;

e) Resposta atempada às questões colocadas pelos seus clientes, disponibilizando informação clara e adequada.

\section{Relacionamento com Concorrentes}

a) A TAP na sua relação com todas as empresas em geral e do sector da aviação em particular, adoptará práticas de concorrência leal, aceitando e respeitando as regras de funcionamento de uma economia de mercado. 
b) A sua actuação reger-se-á por princípios de transparência e correcção, baseada numa valorização competitiva centrada no desempenho, no mérito e na qualidade da sua oferta, não recorrendo a meios desleais para desvio de clientes, nem veiculando mensagens publicitárias falsas e enganosas.

\section{Relacionamento com Fornecedores}

As empresas do Grupo TAP manterằo uma relaçăo de parceria leal e amigável com os seus fornecedores, baseada em procedimentos que em observância das regras do mercado assegurem uma justa partilha dos beneficios e das responsabilidades da cadeia de valor em que operam:

a) As empresas escolherão os səus fornecedores segundo idênticos critérios de exigência ética.

b) O relacionamento com os fornecedores efectuar-se-á segundo processos transparentes, com estrita observância das condições contratuais negociadas.

\section{Relacionamento com Colaboradores}

A gestão das empresas do Grupo TAP desenvolverá políticas que garantam:

a) a dignificação da pessoa, nằo permitindo práticas discriminatórias ou que, de qualquer modo, atentem contra a integridade pessoal e profissional dos colaboradores.

b) plataformas de entendimento baseadas na compatibilização entre a flexibilidade decorrente das exigências da competitividade e a segurança e empregabilidade dos seus colaboradores. 
c) 0 respeito pela qualidade de vida dos colaboradores, reconhecendo o mérito como factor de ganhos de produtividade.

d) o investimento no capital humano, promovendo a formação profissional contínua de todos os colaboradores e valorizando a livre iniciativa.

e) o recrutamento, selecção e aperfeiçoamento dos colaboradores com base em critérios transparentes, objectivos e tecnicamente fundamentados, assegurando a sua orientação por profissionais das respectivas áreas.

f) o incentivo dos seus colaboradores a participar numa cultura da qualidade e produtividade, propiciadora de uma incessante busca de oportunidades de melhoria do desempenho.

\section{Relacionamento Interpessoal}

a) Promover e sustentar condutas e relacionamentos interpessoais urbanos;

b) Serão inaceitáveis quaisquer comportamentos que infundadamente prejudiquem a reputaçăo de colegas, nomeadamente através de julgamentos preconceituosos, boatos ou informaçōes não fundamentadas e não serão toleradas intimidações, discriminaçōes, ameaças e assédios morais ou sexuais sobre os colaboradores, em todas as esferas da vida da Empresa. 


\section{Protecção de Direitos Pessoais}

GRUPOTAP

a) Serão promovidos esforços especiais para garantir a plena igualdade de oportunidades a todos os que colaboram profissionalmente com as empresas do Grupo, dando combate persistente a quaisquer formas de discriminação:

b) Será observado o princípio da não discriminação nomeadamente em relação à ascendência, deficiência, género, etnia, língua, território de origem, religião, convicções políticas e filiação sindical.

c) O direito à reserva da intimidade da vida privada deverá ser respeitado em todas as situações.

d) Os colaboradores portadores de doença não contagiosa devem continuar inseridos no local de trabalho, tanto quanto o permitam a evolução do seu estado de saúde e as exigências do posto de trabalho.

\section{Segurança e Bem Estar no local de trabalho}

O Grupo TAP procurará promover um ambiente de trabalho sadio e seguro, que vise a valorização e o bem-estar, promovendo a confiança, o respeito, a justiça e o estímulo às inovações. Assim:

a) Criará condiçōes para permitir ao colaborador um ambiente facilitador da participação activa na prevenção dos riscos profissionais. 
b) Assegurará condições para que os serviços da empresa avaliem e informem as exigências dos postos de trabalho e dos riscos profissionais, permitindo assim optimizar e adequar os colaboradores à situação de trabalho e assegurar a vigilância da saúde, em função dos riscos a que se encontram expostos no seu local de trabalho.

c) Assegurará as condições para um adequado e responsável funcionamento dos serviços de Segurança, Higiene e Saúde da Empresa, com vista à eliminação/redução dos riscos profissionais, melhoria da qualidade e aumento da produtividade.

\section{Uso de Bens da Empresa}

a) Os recursos das Empresas do Grupo TAP existem para prosseguir os objectivos empresariais das mesmas e assim só podem ser usados para os fins por elas definidos.

b) Os colaboradores devem fazer uma utilização criteriosa dos bens e serviços que lhe estão facultados e evitar desperdicios e mau uso.

10. Ambiente

O Grupo TAP considera que o seu crescimento sustentado pressupōe a compatibilização do desempenho económico com a responsabilidade que assume para com a sociedade e o meio ambiente. Reconhece ainda que a protecção do ambiente é uma responsabilidade de todos, pelo que procura integrar as questōes ambientais em todas as suas actividades. 
Assim, assume os seguintes princípios orientadores:

a) Promover a melhoria continua do seu desempenho ambiental, através do desenvolvimento e implementação de um Plano de Gestão Ambiental;

b) Utilizar práticas e tecnologias eco-eficientes que conciliem o crescimento com a protecção do ambiente;

c) Adoptar uma abordagem de prevenção relativamente às questões ambientais;

d) Prevenir a poluição na origem, reduzindo a quantidade de residuos produzidos, promovendo a sua valorização/reciclagem;

e) Promover iniciativas de divulgação e sensibilização ambiental de colaboradores e fornecedores;

f) Promover a qualidade ambiental em todas as actividades da empresa;

11. Responsabilidade Social

A gestão e os colaboradores do Grupo TAP dedicarão atenção às temáticas da responsabilidade social, sustentabilidade e cidadania empresariais:

a) Promovendo as politicas de Empresa que desenvolvam a responsabilidade social, tanto na sua dimensão interna como na externa;

b) Participando directa ou indirectamente em projectos de intervenção social, actividades civicas, sociais e culturais no seio das comunidades em que estão inseridas;

c) Procurando estimular a disponibilização das suas competências em projectos comunitários, designadamente, através do voluntariado. 
Aprovado em reunião do Conselho de Administração Executivo da TAP -

Transportes Aéreos Portugueses, SGPS, S.A. de 25 de Outubro de 2007 (cf. Acta $n^{\circ} 74$, deliberação n 74.02).

O Conselho de Administração Executivo:

Presidente: $\quad$ (Fernando Pinto)

Administradores: $\quad$ (Michael Conolly)

(Manoel Torres)

(Luiz Mór)

(Jorge Sobral)

(Luis Ribeiro Vaz) 
Anexo 3 - Regulamento Interno de Prevenção e Controlo do Consumo de Álcool, Drogas e Tabaco

Regulamento Interno de Prevencão e Controlo

do Consumo de Álcool, Drogas e Tabaco 


\section{I}

\section{Exposição de motivos}

O flagelo do consumo abusivo de álcool e drogas, que também afecta alguns trabalhadores da Empresa, traduz-se na intoxicação como efeito imediato e agudo e, a longo prazo, tem consequências que, pela sua gravidade, não podem ser ignoradas.

Esses efeitos, designadamente, afectam:

- várias funções físiológicas, nomeadamente hepáticas, digestivas e cardiovasculares;

- as aptidões sensório-motoras com reflexos no tempo de reacção, motricidade, visão, execução de tarefas de vigilância e outras;

- as funções cognitivas a nível de apreensão, decisão, aprendizagem e outras de natureza intelectual;

- a esfera emocional.

A degradação dessas capacidades implica a redução da qualidade do desempenho profissional e traz consequências negativas tanto para o próprio trabalhador, como para os seus colegas e para a Empresa, podendo, em geral, definir-se nos seguintes termos:

a) Consequências para o trabalhador:

Manifesta alterações físicas, de carácter e de comportamento, nomeadamente através de ausência, náuseas, tremor das mãos, tendência para $o$ isolamento, etc..

Progressivamente os problemas físicos e psíquicos agravam-se, caracterizando-se por comportamentos agressivos, nervosismo, irritabilidade. A capacidade de raciocínio e de decisão fica alterada. Intensifica a falta de pontualidade e assiduidade. Ocorrem acidentes que podem provocar ferimentos, incapacidades ou mortes. $O$ trabalhador perde progressivamente auto-estima, alheia-se do ambiente laboral, diminui o zelo e diligência, reduz a produtividade.

b) Consequências para os colegas de trabalho:

Sendo o trabalho de equipa próprio da actividade da Empresa e quase sempre indispensável, qualquer falha de um dos membros afecta o funcionamento do grupo e tem consequências no esforço e na produtividade geral.

O acréscimo de trabalho para os colegas que têm que suprir as deficiências do trabalhador afectado, a princípio tolerado, cedo se traduz numa sobrecarga dificilmente suportável, conduzindo a reclamações, conflitos pessoais, perda de tempo, deficiências de execução das tarefas, agravamento dos riscos de acidente de trabalho, diminuição da produtividade.

Nalguns casos, pode até o trabalhador adicto ao consumo de álcool ou drogas, induzir outros a segui-lo. 
c) Consequências para a Empresa:

A doença, o absentismo, os conflitos e desentendimentos no ambiente de trabalho, os erros de decisão no exercício das tarefas laborais, os acidentes laborais e, em geral, todos os comportamentos conexos com o consumo de álcool e drogas, acarretam na prática, para a Empresa, consequências muito negativas, tais como: aumento dos encargos médicos e do prémio dos seguros, absentismo, designadamente por doença, redução da produção, danos materiais, pagamento de indemnizações, deterioração da imagem dos trabalhadores e da Empresa. Os trabalhadores adictos àqueles consumos, pela sua instabilidade, impōem frequentemente a sua substituição temporária ou definitiva, o que, para além dos encargos directos dai decorrentes, se traduz numa perda de conhecimentos profissionais e experiência, cuja aquisição teve relevantes custos para a Empresa.

Em plano de interesses e de condutas de natureza e alcance diversos, apresenta-se a questão da prevenção e controlo do consumo de tabaco, visando prioritariamente a protecção da exposição involuntária ao fumo do tabaco, mas incluindo também a chamada de atenção para os malefícios do tabagismo para os fumadores e os ganhos para a saúde que justificam o abandono daquele consumo.

\section{II}

\section{Fundamentação de facto}

As razões acima apontadas, pela sua gravidade e consequências, impõem à Empresa, enquanto entidade empregadora, a adopção de medidas necessárias e adequadas, visando assegurar e controlar a higiene, saúde e segurança nos locais de trabalho, bem como o bem estar geral e a organização disciplinada dos seus meios de produção. De resto, a preocupação e a actuação neste sentido constituem deveres indeclináveis que impendem sobre a Empresa: dever de boa gestão, dever de respeito e protecção dos direitos $e$ interesses legítimos de todos os seus trabalhadores, por forma a que os serviços que presta aos seus clientes mereçam cada vez maior aceitação e procura. Preocupações, aliás, que se inserem num vasto leque de convenções internacionais, directivas, recomendações, diplomas legais e tomadas de posição dos Estados e dos parceiros sociais.

Numa Empresa de transporte aéreo de passageiros, carga e correio, envolvendo actividades relacionadas com esse transporte e essenciais para a respectiva segurança, como a manutenção de aeronaves, com vários milhares de trabalhadores ao seu serviço, reveste particular acuidade a segurança de pessoas e bens, sejam elas clientes ou trabalhadores. Importa assim assegurar que todos os trabalhadores ao serviço da Empresa se encontrem no pleno uso das suas capacidades, por forma a garantir a produtividade e a minorar o risco de acidentes de trabalho, como é, aliás, seu dever legal e contratual. 
Tem-se presente que os trabalhadores consumidores de álcool em excesso, de estupefacientes e de substâncias psicotrópicas, devem ser encarados como que necessitados e merecedores de assistência médica, tudo devendo ser feito para os tratar.

A Empresa não descura este aspecto, designadamente no âmbito da medicina do trabalho, promovendo o seu acompanhamento e encaminhamento, quando necessário, para organismos vocacionados para o seu tratamento e recuperação.

A hierarquia e os órgãos encarregados da gestão e administração de pessoal colaborarão no acompanhamento e recuperação dos trabalhadores afectados pelo consumo de álcool e toxicodependência, seguindo as prescrições da medicina no trabalho e propondo, quando necessário, medidas adequadas necessárias para o efeito.

Por outro lado, na linha de acção iniciada em 2002, a Empresa compromete-se activamente na prevenção e na ajuda à superação da dependência do consumo de tabaco, protegendo os interesses dos não fumadores e a salubridade do ambiente de trabalho.

\section{III \\ Fundamentação legal}

A possibilidade de introdução por parte das entidades empregadoras de sistemas de controlo dos referidos consumos, decorre, designadamente, dos seguintes preceitos legais:

Art ${ }^{\circ} 150^{\circ}$ do Código do Trabalho, que estabelece que dentro dos limites decorrentes do contrato e das normas que o regem, compete ao empregador fixar os termos em que deve ser prestado o trabalho.

Art ${ }^{\circ} .121^{\circ} \mathrm{n}^{\circ} 1$ al. d) do mesmo diploma, que estipula que o trabalhador deve obedecer à entidade patronal em tudo o que respeite à execução e disciplina do trabalho, salvo na medida em que as ordens e instruções se mostrem contrárias aos seus direitos e garantias.

Art ${ }^{\circ} .290^{\circ} \mathrm{n} .^{\circ} 1$, ainda do mesmo diploma, que estabelece que não dá direito a reparação (leia-se, indemnização) o acidente:

a) que for dolosamente provocado pelo sinistrado ou provier de acto seu ou omissão, que importe violação, sem causa justificativa, das condições de segurança estabelecidas pela entidade empregadora ou previstas na lei;

b) que resultar da privação permanente ou acidental do uso da razão do sinistrado, nos termos da lei civil, salvo se:

- tal privação derivar da própria prestação do trabalho,

- for independente da vontade do sinistrado

- ou se a entidade empregadora ou o seu representante, conhecendo o estado do sinistrado, consentir na prestação. 
$\mathrm{O} \operatorname{art}^{\circ} .274^{\circ} \mathrm{n} .{ }^{\circ} 1$, também do Código do Trabalho, obriga o trabalhador a:

- cumprir as prescrições de segurança, higiene e saúde no trabalho estabelecidas nas disposições legais e em instrumentos de regulamentação colectiva do trabalho, bem como as instruçôes determinadas com esse fim pelo empregador;

- zelar pela sua segurança e saúde, bem como pela segurança e saúde das outras pessoas que possam ser afectadas pelas suas acções ou omissões no trabalho;

- cooperar, na empresa, estabelecimento ou serviço, para a melhoria do sistema de segurança, higiene e saúde no trabalho.

$\mathrm{O} \operatorname{art}^{\circ} 235^{\circ}$ da Lei $\mathrm{n}^{\circ} 35 / 2004$, de 29 de Julho, impõe ao empregador o dever de promover a realização de exames de saúde, tendo em vista verificar a aptidão física e psíquica do trabalhador para o exercicio da actividade.

Por fim, o art $396^{\circ} \mathrm{n} .^{\circ} 3$ alineas a) e h) do Código do Trabalho, fixa que a desobediência ilegítima às ordens dadas por responsáveis hierarquicamente superiores e a falta culposa da observância de normas de higiene e segurança no trabalho, tornam imediata e praticamente impossivel a subsistência da relação de trabalho, constituindo, por isso, justa causa de despedimento.

Em relação à prevenção e controlo do tabagismo, a Lei n. ${ }^{\circ} 37 / 2007$, de 14 de Agosto, estabelece os principios e normas gerais sobre a matéria, cabendo à Empresa determinar a respectiva concretização e execução nos locais de trabalho.

Perante tudo o exposto, ouvidos a Comissão de Trabalhadores e os Sindicatos representativos dos trabalhadores, a Empresa, no uso do poder regulamentar que the é próprio, estabelece o seguinte

\section{Regulamento Interno de Prevenção e Controlo do Consumo de Álcool, Drogas e Tabaco}

\section{Objecto}

1.1. O presente Regulamento fixa os termos a que deve obedecer a prevenção e controlo do consumo de bebidas alcoólicas, de substâncias estupefacientes e psicotrópicas e de tabaco na Empresa, tem como finalidade prioritária a prevenção contra o risco de acidentes de trabalho através da diminuição do consumo de bebidas 
alcoólicas e da erradicação das situações de trabalho sob os efeitos do consumo daquele tipo de substâncias $e$, consequentemente, a melhoria da saúde dos trabalhadores e dos niveis de segurança no trabalho e da prestação de serviços de transporte de passageiros, carga e correio e de manutenção de aeronaves.

1.2. Para esse efeito, o presente Regulamento define:

a) Os procedimentos a adoptar nos exames de admissão à Empresa, estipulados no Anexo I.

b) Os procedimentos a adoptar pela hierarquia e pelos serviços de saúde, higiene e segurança no trabalho para a identificação, acompanhamento e tratamento de doentes alcó́licos e toxicodependentes.

c) Os meios a utilizar na detecção e controlo do alcoolismo e da toxicodependência, bem como a aplicação e a localização desses meios.

d) As regras a que ficam sujeitas a venda e o consumo de bebidas alcoólicas e de tabaco nas instalações da Empresa.

e) A responsabilidade pelas acções de informação e de formação dos trabalhadores nos domínios da prevenção e do controlo do alcoolismo e do consumo de estupefacientes e psicotrópicos e do consumo de tabaco.

1.3. O presente Regulamento não revoga nem substitui a regulamentação específica aplicável a profissões ou a grupos profissionais definidos ou em áreas de actividade identificadas, sujeitos a regras, limitações ou condicionamentos especiais, quando mais exigentes do que os agora estabelecidos.

2. Deteç̧ão e acompanhamento de doentes alcoólicos ou toxicodependentes

2.1 Os exames médicos prévios à admissão na Empresa incluirão o despiste da dependência do candidato relativamente a consumos de álcool estupefacientes e psicotrópicos, tendo em consideração as exigências das funções a desempenhar.

2.2 Na vigência da relação laboral, os casos de doença alcoólica, essencialmente caracterizados pela situação de dependência do álcool, ou de toxicodependência, estão sujeitos a detecção $e$ acompanhamento.

2.3 A detecção dos presumíveis doentes alcoólicos ou toxicodependentes compete fundamentalmente aos serviços de medicina, saúde, higiene e segurança no trabalho. 
2.4 Os serviços de medicina do trabalho aconselharão os doentes alcoólicos e toxicodependentes e os trabalhadores dependentes de consumo de tabaco e encaminhá-los-ão, sempre que possivel, para os organismos médicos vocacionados para o seu tratamento e recuperação, estabelecendo os necessários contactos com estes organismos.

2.5 A hierarquia e os órgãos encarregados da gestão de pessoal colaborarão no acompanhamento e recuperação dos doentes alcoólicos e toxicodependentes, seguindo as prescrições dos serviços de medicina do trabalho e propondo, quando necessário, medidas adequadas para o efeito.

\section{Controlo técnico de alcoolemia e da toxicologia}

3.1 Os candidatos à admissão na Empresa e todos os trabalhadores da mesma, estes por dever de obediência, estão sujeitos ao controlo do consumo de álcool e de estupefacientes e psicotrópicos.

3.2 A alcoolemia é determinada por análises laboratoriais de sangue e, também, por testes de sopro, que indicam a percentagem de álcool no sangue e sendo expressa designadamente em gramas/litro.

$3.3 \mathrm{O}$ controlo da toxicologia é realizado através da análises laboratoriais ao sangue e/ou urina.

3.4 Todos os trabalhadores poderão ser sujeitos a controlo nos termos deste Regulamento nas seguintes situaçōes:

a) indícios de consumo de álcool ou de estupefacientes ou psicotrópicos;

b) acidente de trabalho;

c) anterior controlo de alcoolemia ou toxicologia positivo;

d) acidente, quasi-acidente ou incidente de circulação;

e) sorteio.

3.5 A determinação de sujeição a controlo da alcoolemia ou da toxicologia deve respeitar sempre os requisitos de privacidade.

3.6 Deverão ser prioritariamente submetidos a controlo da alcoolemia e da toxicologia os trabalhadores de sectores cujos postos de trabalho tenham, directa ou indirectamente, maiores implicações na segurança da circulação e envolvam maiores riscos profissionais.

3.7 As análises laboratoriais de sangue e de urina são efectuados pelos serviços de medicina, saúde, higiene e segurança no trabalho e os testes de sopro e de urina por pessoal devidamente qualificado e credenciado por aqueles serviços. 
3.8 Cabe à Empresa, directamente ou com a participação ou por intermédio de entidade contratada para o efeito, a definição dos equipamentos médicos e de controlo da alcoolemia ou toxicologia a utilizar, homologados nos termos da lei, os quais podem pertencer à Empresa ou a outras entidades, a formação do pessoal autorizado a utilizar esses equipamentos, bem como o apoio técnico a todas as acções que visem a prevenção e controlo do alcoolismo ou da toxicodependência.

3.9 Todos os intervenientes, em qualquer fase do processo, incluindo o sorteio, estão sujeitos a um especial dever de sigilo, sendo os resultados apurados rigorosamente confidenciais, salvo na parte e na justa medida em que relevem para o apuramento de eventual responsabilidade disciplinar.

4. Detecção da prestação de trabalho sob a influência do álcool ou da toxicologia

4.1 Compete à chefía directa ou à representação da hierarquia no local de trabalho providenciar no sentido do accionamento dos mecanismos de controlo previstos no presente Regulamento.

4.2 Todos os trabalhadores devem dar o seu apoio activo na prevenção e controlo da prestação de trabalho sob a influência do álcool ou de substâncias estupefacientes ou psicotrópicas.

4.3 O controlo da alcoolemia ou toxicologia deverá ser sempre efectuado em condições adequadas de privacidade.

4.4 Quando em presença de indícios sérios de influência do álcool ou de substâncias estupefacientes ou psicotrópicas, apresentados por trabalhador em vias de iniciar, reiniciar ou já a prestar trabalho, não seja possivel utilizar de imediato os equipamentos de controlo, compete à chefia directa ou ao representante da hierarquia no local de trabalho tomar as medidas adequadas para garantir a segurança do trabalhador ou de outras pessoas em situação de risco, bem como das instalações, equipamentos e outros bens de que a Empresa seja possuidora ou pelos quais seja responsável.

4.5 Após tomar as medidas que se mostrarem adequadas à situação concreta, a chefia directa ou o seu representante no local de trabalho diligenciarão no sentido de o trabalhador ser submetido a controlo da alcoolemia ou da toxicologia ou a observação clínica. 
4.6 A inaptidão do trabalhador após o controlo da alcoolemia ou toxicologia, será comunicada ao trabalhador e à hierarquia directa ou o seu representante no local de trabalho, através de documento cujo modelo consta do Anexo II e com carácter de confidencialidade.

5. Procedimentos a adoptar nos casos de prestação de trabalho sob a influência do álcool ou de substâncias estupefacientes ou psicotrópicas

5.1 Constitui violação dos deveres dos trabalhadores:

a) A prestação de trabalho sob a influência do álcool ou de substâncias estupefacientes ou psicotrópicas;

b) O consumo ou a posse, nos locais de trabalho, de bebidas alcoólicas, qualquer que seja a graduação, ou de quaisquer substâncias estupefacientes ou psicotrópicas ;

c) A transacção, a qualquer título, nos locais da Empresa, de bebidas alcoólicas (qualquer que seja a graduação) ou de quaisquer substâncias estupefacientes ou psicotrópicas.

5.2 A título indicativo e para efeito do autocontrolo do consumo de álcool, atender-se-á à equivalência entre a quantidade de bebidas alcoólicas e as correspondentes taxas de alcoolemia indicadas no Anexo III.

5.3 Sempre que o resultado do controlo de alcoolemia seja igual ou superior a 0,5 gramas/litro, o trabalhador será considerado sob a influência do álcool e declarado pela sua chefia directa inapto para o início ou a continuação da prestação de trabalho.

5.4 Sempre que no controlo da toxicologia seja detectada a presença de substâncias estupefacientes ou psicotrópicas não permitidas por lei nem ministradas sob prescrição médica, susceptíveis de colocarem em causa a segurança dos trabalhadores ou de outras pessoas em situações de risco, bem como das instalações, equipamentos e outros bens, é aplicado, com as necessárias adaptações, o disposto no número anterior.

5.5 O trabalhador que recusar sujeitar-se ao controlo da alcoolemia ou toxicologia será declarado pela sua chefia directa inapto para o trabalho.

5.6 A declaração da inaptidão prevista nos números anteriores implica a impossibilidade de prestação de trabalho até ao termo do período de trabalho diário ou do serviço de voo, bem como a perda da retribuição correspondente. 
5.7 A prestação de trabalho sob a influência de álcool ou de substâncias estupefacientes ou psicotrópicas, bem como a recusa à sujeição ao controlo de alcoolemia ou toxicologia, constituem infracções disciplinares, sujeitas ao procedimento correspondente.

5.8 Os resultados do controlo de alcoolemia ou toxicologia são confidenciais, sem prejuizo das exigências inerentes ao exercício do poder disciplinar da Empresa.

5.9 disposto nos números anteriores não é aplicável aos trabalhadores que tenham sido previamente diagnosticados como doentes alcoólicos ou toxicodependentes e aceitem submeter-se ao tratamento adequado previsto neste Regulamento, salvo quando violem o programa de recuperação especificamente acordado com o trabalhador.

5.10 Para efeitos de tratamento adequado, poderá a TAP privilegiar o encaminhamento do trabalhador para a situação de incapacidade temporária por doença a cargo da Segurança Social, sem prejuizo do acompanhamento no âmbito da Empresa.

5.11 Sem prejuizo da faculdade que assiste ao trabalhador de recorrer a outros meios de contraprova legalmente admitidos, designadamente testes sanguíneos realizados nos laboratórios de entidades qualificadas e autorizadas para o efeito, todo o trabalhador submetido a controlo de alcoolemia ou toxicologia, por teste de sopro ou colheita de urina, respectivamente, cujo resultado seja positivo, poderá, se assim o entender, submeter-se a novo teste nos dez minutos imediatamente subsequentes.

$5.12 \mathrm{O}$ segundo teste, quando confirme o resultado do primeiro, será custeado pelo trabalhador.

5.13 A Empresa poderá determinar a suspensão do procedimento disciplinar instaurado com fundamento na prática de qualquer das infraç̧ões previstas neste Regulamento aos trabalhadores diagnosticados como dependentes do álcool ou toxicodependentes, que aceitem sujeitar-se à realização de tratamento adequado, bem como considerar essa realização como comportamento relevante no âmbito daquele procedimento.

\section{Consumo e venda de álcool em instalações da Empresa}

6.1 Não é permitida a venda de bebidas alcoólicas, qualquer que seja a graduação, nos locais da Empresa, nomeadamente nos respectivos refeitório e bares. 
6.2. O disposto no número anterior não é aplicável nos locais da Empresa destinados ao serviço a passageiros e em relação a estes (lounges e aeronaves).

6.3 Sem prejuizo da proibição absoluta específica de certos grupos profissionais, é vedado aos trabalhadores ingerir bebidas alcoólicas antes, durante ou após o período de trabalho, nos locais onde a Empresa desenvolve a sua actividade.

\section{Proibição de fumar}

7.1Não é permitida a venda de tabaco nos locais da Empresa, nomeadamente nos respectivos refeitório e bar.

7.2. O disposto no número anterior não é aplicável nos locais da Empresa destinados ao serviço a passageiros e em relação a estes (lounges e aeronaves).

7.3 É proibido fumar nas instalações da Empresa fora dos locais expressamente sinalizados para o efeito.

\section{Formação e informação do pessoal}

8.1 A Empresa, directamente ou por intermédio de entidade contratada para o efeito, promoverá acções de formação e informação do seu pessoal, tendo em vista a prevenção e a diminuição da incidência e das consequências de consumo do álcool, de substâncias estupefacientes ou psicotrópicas ou de tabaco.

8.2. A execução destas acções cabe à TAP/Serviços, em estreita articulação com as entidades contratadas em matéria de controlo de alcoolemia ou toxicologia e de medicina do trabalho e em colaboração com a hierarquia, competindo-lhe, designadamente:

a) coordenar acções de formação e informação sobre prevenção do alcoolismo, da toxicodependência e do consumo de tabaco.

b) coordenar as acçôes que, a diversos niveis, visem o controlo e eliminação dos efeitos do consumo de álcool, de substâncias estupefacientes ou psicotrópicas e de tabaco.

c) propor medidas que considerar necessárias.

d)acompanhar e dinamizar a aplicação do presente Regulamento e propor a sua revisão.

e) elaborar anualmente um relatório da actividade desenvolvida e dos respectivos resultados.

8.3. Salvaguardado o princípio da confidencialidade e a privacidade dos trabalhadores envolvidos, o relatório mencionado na alínea e) do ponto 8.2 ., será enviado à C.T.. 


\section{Disposições finais}

9.1. O disposto no presente Regulamento e a respectiva aplicação têm que ser entendidos e serão pautados pelos princípios e normas consagradas na Lei de Protecção de Dados.

9.2. $O$ presente Regulamento entra em vigor no dia 17 de Março de 2008.

Lisboa, 17 de Março de 2008

O Conselho de Administração 
ANEXO I

\section{Procedimentos a adoptar nos exames de admissão}

- A todos os candidatos, serão efectuados testes de despistagem do consumo de drogas;

- O conjunto de exames auxiliares de diagnóstico, análises e testes são os que a Medicina do Trabalho considerar necessários para a emissão de juizo sobre a aptidão do candidato para o desempenho das respectivas funções.

- Nos protocolos clínicos e analíticos em geral e/ou para cada profíssão especifica, serão identificados todos os exames, meios de diagnóstico, análises e testes necessários, a fim de permitir a devida informação prévia a todos os candidatos quando encaminhados para os serviços médicos;

- Os candidatos à admissão serão previamente informados sobre todos os exames, análises e testes a que vão ser sujeitos, obtendo-se o consentimento expresso dos mesmos;

- Se por parte do candidato existir recusa de sujeição aos exames determinados, a mesma deve ser registada formalmente e determinará a exclusão do candidato do processo de selecção;

- Os resultados dos actos médicos realizados poderão ser comunicados aos candidatos com as clarificações/esclarecimentos adequados;

- A TAP será informada estritamente sobre a aptidão para o posto de trabalho a que se candidata, em impresso próprio designado por ficha médica de aptidão (Portaria $n^{\circ} 1031 / 2002$, de 10 de Agosto ). Neste documento não constará qualquer referência ao/s diagnóstico/s que determinaram o juizo da aptidão. 
ANEXO III

Equivalência entre a quantidade de bebidas alcoólicas e as correspondentes taxas de alcoolemia

As várias bebidas alcoólicas vulgarmente usadas, devido a terem diferentes graduações, podem fornecer ao organismo idênticas quantidades de álcool, se ingeridas em volumes diferentes, como se exemplifica na figura seguinte:

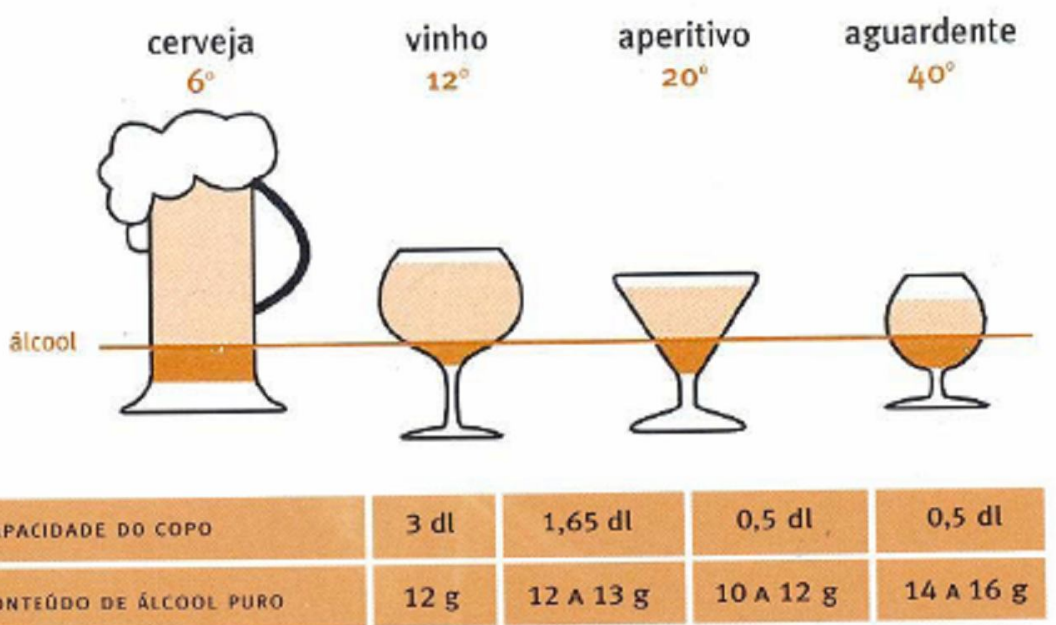

Nos indivíduos em jejum a absorção faz-se em 15-20 minutos, havendo factores que podem alterar a velocidade dessa absorção, como por exemplo: a concentração de álcool e a composição da bebida, o estado da mucosa gástrica e duodenal e a ingestão simultânea de alimentos.

A alcoolémia, taxa de álcool no sangue que traduz a impregnação alcoólica do indivíduo em determinado momento, é calculada tendo em conta o peso de álcool puro consumido (em gramas), o peso corporal (em $\mathrm{Kg}$ ) e um coeficiente de correcção ( homem - 0,7 ; mulher - 0,6 ; no curso das refeições - 1,1). 